\title{
Analysis of the contribution of the block-soil contact in piled foundations
}

\author{
Jean Rodrigo Garcia ${ }^{a *}$ (iD \\ Paulo José Rocha de Albuquerque ${ }^{b}$ \\ a Universidade Federal de Uberlândia, Programa de Pós-Graduação em Engenharia Civil, Uberlândia, MG, Brasil. E-mail: jean.garcia@ufu.br \\ b Universidade Estadual de Campinas, Programa de Pós-Graduação em Engenharia Civil, Campinas, SP, Brasil. E-mail: pjra@unicamp.br \\ * Corresponding author
}

http://dx.doi.org/10.1590/1679-78255565

\begin{abstract}
Geotechnical engineering has often been challenged by demands from technically and economically bold construction projects, such as that of tall buildings. The architectural requirements of these buildings have increased and concentrated the loads from structural systems without proportionally increasing plant area. New forms of using load capacity and settlement control have been assessed to optimize conventional designs. Thus, piled foundations started to allow for the contribution of block-soil contact, being conceptually named piled raft. In this sense, this study analyzed the contribution of contact in piled foundations composed of one, two, three and four instrumented bore piles $25 \mathrm{~cm}$ in diameter ( $\phi$ ) and $5 \mathrm{~m}$ in length (L). Experimental results showed a $21 \%$ average contribution of block-soil in relation to the total piled foundation capacity. This result demonstrates the need to re-evaluate traditional calculation requirements, aiming at rationalizing the geotechnical design and improving the overall safety/stability of the system.
\end{abstract}

\section{Keywords}

Piled foundation, instrumented piles, effect contact

\section{INTRODUCTION}

The growth of large urban centers and the verticalization of cities has challenged geotechnical engineering, demanding technically and economically bold projects that meet technical and economic criteria. The architectural requirements of tall buildings are an example for the use of the piled raft technique, which seeks to solve the problem of load increase and concentration arising from structural systems. Thus, piled foundations started to allow for the contribution of block-soil contact, conceptually named piled raft. According to Mandolini et al. (2013), the piled raft concept considers piles cooperating with rafts instead of being considered an alternative to this shallow foundation element.

Physically, a pile group (or pile block), which is a traditional foundation form, can be considered a piled raft when the connecting block between the piles contacts the soil, thus fulfilling the shallow foundation element role (Sales, 2000).

Using the piled raft technique becomes an interesting solution for geotechnical projects, since it initially promotes an increase in the system load capacity, decrease in pile length in relation to conventional pile block designs, and the standardization of settlements.

Several studies have been developed regarding of piled raft foundation. Nevertheless, they are mainly theoretical, numerical or reduced-scale modeled, for example, the studies from Chung et al. (2013), De Sanctis e Mandolini (2003, 2006), Janda et al. (2009), Leung et al. (2010), Makarchian and Poulos (1994), Mandolini et al. (2013), Novak et al. (2005), Omeman (2012), Poulos (2001), Poulos et al. (2011), Russo et al. (2013) Viggiani et al. (2012).

The rising of the heavy building construction and restraint of differential settlements have led to increased studies of piled raft as a foundation technique, and the outcomes reveal the importance of understanding the behaviour of this 
type of foundation. Some foundation standards and manuals contextualize this type of foundation (British Standard 2015 - BS 8004, Australian Standard 2009 - AS 2159), Institute of Civil Engineers, 2012 and Eurocode 7, 1997).

Experimental studies on piled rafts, particularly the full-scale testing, are unusual, therefore the relevance of the present study. It evaluated the behaviour of full-scale instrumented piles which were set on blocks of one to four piles. The main objective of this study was to analyze the load transfer mechanism in piled rafts, identifying the load percentage absorbed by each of the elements (raft and piles), and then compare the results to others from existing research literature.

There are several types of piles that can be employed in this type of foundation. In this study, the option chosen was a small diameter bored pile due to it's simplicity of execution and large-scale application in southeastern Brazil, which concentrates the most significant construction industry numbers.The piles were performed on the Experimental Site II of the University of Campinas (Universidade Estadual de Campinas) which were subjected to a slow maintained load test (SML).

The results of the study presented in this article are part of a research project funded by Fundação de Amparo à Pesquisa do Estado de São Paulo (FAPESP - process: 2011/17959-3), developed at the Universidade de Campinas (UNICAMP). This project analyzed the behavior of piled rafts in the soil in the region of Campinas, SP, Brazil.

\section{PILED RAFTS}

Piled rafts can be characterized as the result of load distribution among the elements, piles and rafts, using a coefficient, $\alpha_{p r}$, proposed by Mandolini (2003):

$\alpha_{p r}=\frac{\sum_{i=1}^{n} Q_{p i l e, i}}{Q_{P R}}$

Where: $Q_{p R}$ is the total load applied to the piled raft $\left(Q_{\text {pile, }}\right)$ is the load absorbed by pile i and $\alpha_{p r}$ represent the part of the total load carried by the piles; $\alpha_{\mathrm{pr}}=1$ represents a pile group in which the top is not in contact with the soil and for $0<\alpha_{\mathrm{pr}}<1$, the system functions as a piled raft (Figure 1).

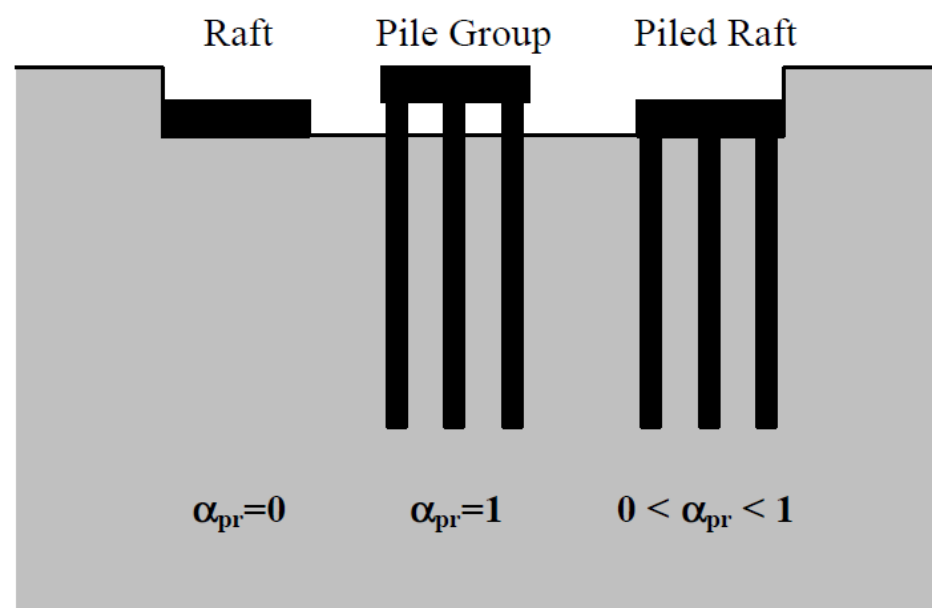

Figure 1: Foundation system (Mandolini, 2003)

There are three design philosophies regarding piled raft designs (Randolph, 1994):

- Conventional approach: in this philosophy, the piles are designed as groups that bear the greater portion of the total load, however, it is considered that a portion of the load is absorbed by the raft/block, principally for the maximum load capacity. In this approach, the length and diameter of the piles are calculated separately, with a satisfactory safety factor value and piled raft behavior being controlled by the pile group. In project load situations, they can be mostly linear since the piles are working close to the workload. For Mandolini (2003), the conventional approach occurs when $\alpha p r=1$, i.e., the entire load is born by the piles. It is equivalent to a virtual performance of a pile group instead of actual behavior of a piled raft; 
- $\quad$ Control of differential settlements: the piles are strategically positioned to limit the total settlements to acceptable levels. Thus, differential settlements are reduced because of the limitation of total settlements;

- $\quad$ Criterion for partial or total mobilization of the piles: this approach establishes that the piles must be designed to absorb between $70 \%$ to $80 \%$ of the shear load capacity, from which point plastic/creep deformations begin to occur. This approach installs sufficient piles under the raft so contact stress between the raft and the soil is reduced to smaller values than the pre-consolidation stress of the soil.

According to Randolph (1994), a rational design procedure must involve three stages:

- $\quad$ Preliminary stage: analyzes the feasibility of a piled raft. The design performance is evaluated without the piles. Estimates of vertical and lateral load, and maximum and differential settlements are made using conventional techniques. The philosophy of the project is chosen considering the load that the horizontal element (raft) can receive. If the horizontal element contributes to a small load capacity percentage of the foundation element, then the philosophy adopted will tend towards a conventional approach. If the top presents adequate resistance - or close to load capacity -, but does not meet total or differential settlement criteria, then the piles should be considered as settlement reducers or be adopted as totally mobilized. Load capacity is evaluated based on failure type, which may occur in individual piles or over the entire soil block. In failure analysis for individual piles, load capacity is the sum of pile resistance and contact caused by the raft, and can be described by the following general formula:

$Q_{P R, u l t}=\alpha_{U R, u l t} \cdot Q_{U R, u l t}+\alpha_{P G, u l t} \cdot Q_{P G, u l t}$

Where: $\alpha_{U R, u l t}$ and $\alpha_{P G, u l t}$ represent the efficiency of the raft and of the piles group when combined in a piled raft, respectively.

In the shear analysis for soil block failure analysis, the skin friction strength $\left(\tau_{\mathrm{s}}\right)$ and base $\left(q_{\mathrm{B}}\right)$, is mobilized by the vertical surface and the perimeter base area of the piles, respectively. Load capacity is the lesser value between the two failure types.

$$
Q_{B F}=\tau_{S} \cdot A_{S}+q_{B} \cdot A_{B}
$$

The study of settlements can be done using a few simple methods that calculate piled raft strength and load distribution between the piles and the top.

- Second stage: evaluates general characteristics of the piles and where these are required. This study is more detailed. The pile requirement is based on foundation loading, in the following situations: at the moment and shear maximum efforts that exceed the allowable structural value of the horizontal element; contact pressure exerted by the horizontal element on the soil exceeds its allowable value; the total settlement is greater than the allowable value.

- Final stage: in this stage, the number, location and optimal configuration of the piles is obtained. The detailed distribution of settlements, moments and shear strengths on the horizontal element are analyzed, as well as the loads and moments on the piles.

The first and second stages involve relatively simple calculations. However, the final stage requires a suitable computer program that rationally considers the effects of the interaction between the soil, the piles and their surface. It can also be done by experimental analysis, which is presented on this paper. The superstructure effects can also be considered.

Load-settlement behavior of the piled raft can be observed in the curves presented in Figure 2. Curve 0 only represents the raft behavior (shallow element or block), in which the settlements are higher and may be excessive for the workload in some cases. Curve 1 represents the behavior of a piled raft system, which is governed by pile group behavior and may be linear with the design load. In this case, the piles absorb most of the loads. Curve 2 represents creep behavior, in which piles operate at a low safety factor, but, due to the small number of piles, the raft absorbs more load than curve 1. Curve 3 represents the strategy using piles as settlement reducers, using the total pile capacity on the design load. Consequently, the load-settlement curve may not be linear in the design load; however, the total foundation system has an adequate safety margin and settlement criteria is achieved. Thus, the project described by curve 3 is acceptable and can be considered the most economical (Poulos, 2001). 
The trilinear analysis of the resistance mobilization of the piled raft according to the applied loads (Figure 3).

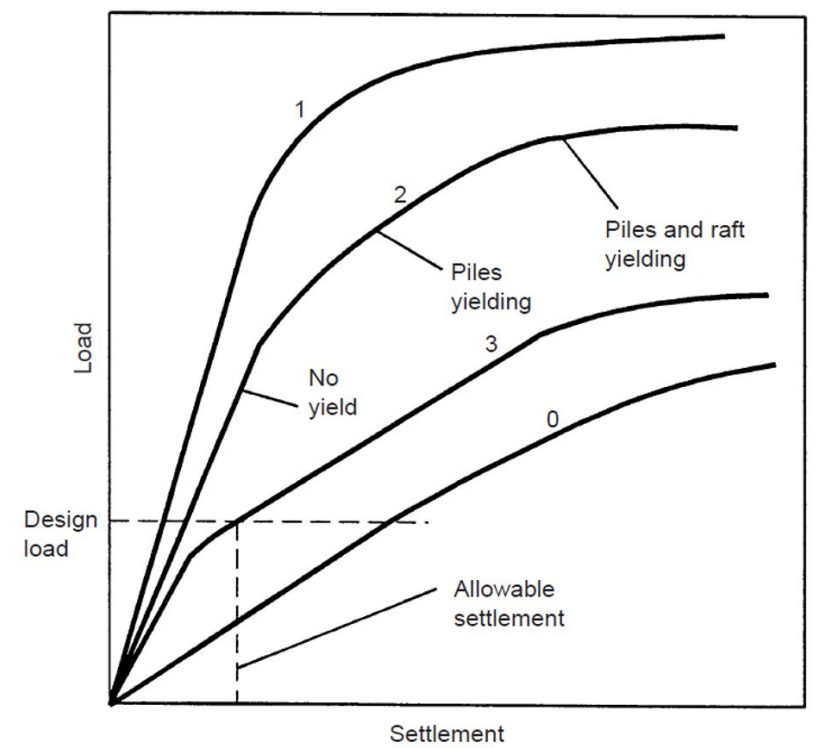

Figure 2: Simplified load-settlement curve for preliminary analysis (Poulos 2001).

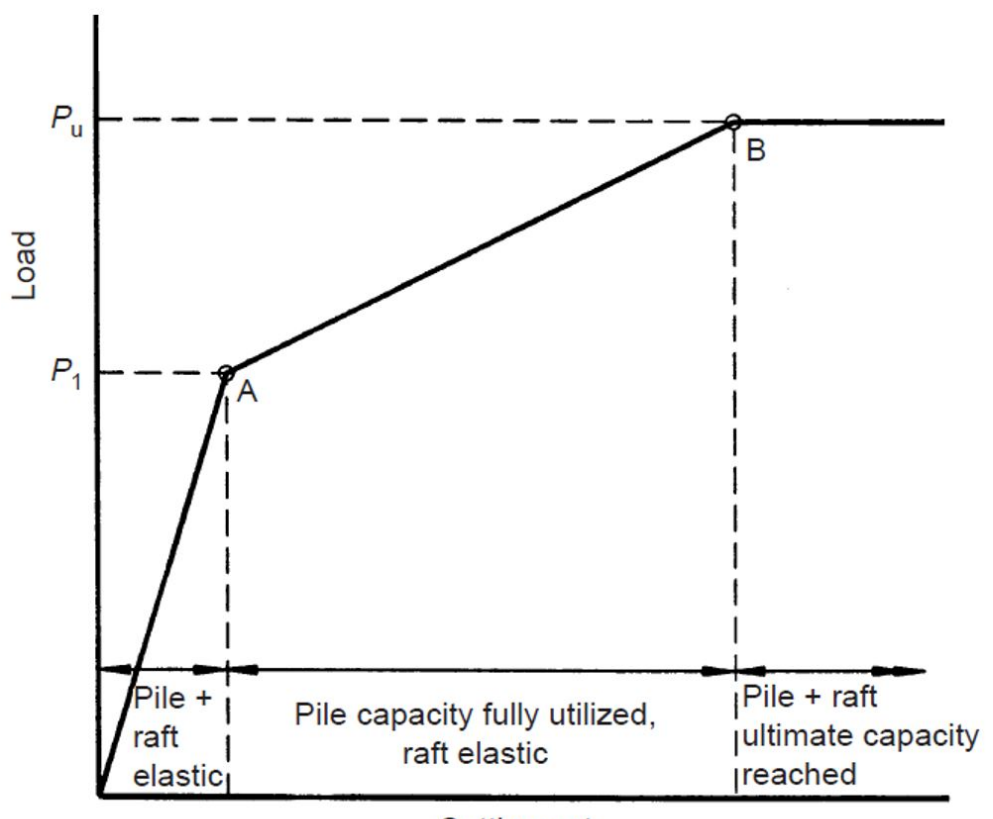

Settlement

Figure 3: Load-settlement curves for piled rafts according to different design philosophies (Poulos 2001).

According to Randolph (1994), stiffness is the ratio between a particular load and the displacement it causes. Thus, up to point $A$ of the Figure 2 graph, the settlement of a foundation is given by:

$\mathrm{w}=\frac{\mathrm{P}}{\mathrm{K}_{\mathrm{PR}}}$

Where: $w$ is the settlement, $K_{P R}$ is the stiffness of the piled raft foundation and $P$ is the load applied on this foundation.

After A point, the settlement of this foundation can be written as follows:

$W=\frac{P_{A}}{K_{P R}}+\frac{P-P_{A}}{K_{R}}$ 
Where: $w$ is the settlement, $K_{P R}$ is the stiffness of the piled raft foundation and $P$ is the load applied on this foundation.

The method uses the value of the initial tangent stiffness of the isolated pile $\left(K_{P}\right)$ and the raft $\left(K_{R}\right)$, obtained from the load proof graph or theoretically estimated, and the raft-pile interaction factor $\left(\alpha_{r p}\right)$, to estimate piled raft stiffness $\left(K_{P R}\right)$. (Randolph, 1994) proposed the estimation of the piled raft stiffness using the following equation:

$\mathrm{K}_{\mathrm{PR}}=\frac{\mathrm{K}_{\mathrm{PG}}+\left(1-2 \cdot \alpha_{\mathrm{rp}}\right) \cdot \mathrm{K}_{\mathrm{R}}}{1-\alpha_{\mathrm{rp}}^{2} \cdot\left(\mathrm{K}_{\mathrm{R}} / \mathrm{K}_{\mathrm{PG}}\right)}$

Where: $K_{P G}, K_{R}$ and $K_{P R}$ are the stiffness of the piles group, raft and piled raft, respectively. $K_{P G}$, can be obtained from the load-settlement curve of the isolated (test) pile using the equation proposed by Fleming et al. (1992) for the stiffness of a piles group $\left(\mathrm{K}_{\mathrm{PG}}\right)$.

$\mathrm{K}_{\mathrm{PG}}=\mathrm{K}_{\mathrm{P}} \cdot(\mathrm{n})^{1-\mathrm{e}}$

Where: $\mathrm{n}$ is the number of piles and the exponent varies from 0.3 to 0.5 for friction piles.

Pile stiffness can be expressed using the equation proposed by (Sales 2000):

$\mathrm{K}_{\mathrm{P}}=\frac{\mathrm{P}}{\delta}$

Where: $\mathrm{P}$ is the load applied on the pile and $\delta$ is the displacement caused by action on P load at the top of the pile.

The interaction factor of the raft with the pile, $\alpha_{r p}$ is

$\alpha_{r p}=1-\frac{\ln \left(r_{c} / r_{0}\right)}{\zeta}$

Where: $r c$ is the mean radius of the element that goes on top of the pile (corresponding to an area equal to the raft area divided by the number of piles); $r_{0}$ is the pile radius; $\zeta=\ln \left(r_{m} / r_{0}\right) ; r_{m}=\{0.25+\xi \cdot[2.5 \cdot \rho \cdot(1-v)-0.25]\} \cdot L ; \xi=E_{s l} / E_{s b}$; $\rho=E_{\text {sav }} / E_{s l} ; V$ is Poisson's coefficient of the soil; $L$ is the pile length; $E_{s l}$ is Young's modulus of the soil at the pile tip level; $E_{s b}$ is Young's modulus of the resisting layer below the pile tip; Esav is Young's modulus over the pile stem portion Poulos (2001).

The modulus of elasticity was obtained through semi-empirical correlations developed for tropical soils by (Teixeira and Godoy 2016):

$E_{s}=\alpha \cdot q_{c}$

Where: $\alpha$ is the coefficient related to the type of soil, and qc is the strength of the tip obtained through the CPT test representing the analyzed layer.

Mandolini 2003 argues that the PDR method allows the use of hyperbolic relationships to predict curves for loaddisplacement of piled rafts, which may assist in obtaining an appropriate behavior of foundations. The piled raft stiffness $\left(K_{P R}\right)$ is:

$\mathrm{K}_{\mathrm{PR}}=\mathrm{X} \cdot \mathrm{K}_{\mathrm{PG}}$

Where:

$X=\frac{1-0.6 \cdot\left(\mathrm{K}_{\mathrm{R}} / \mathrm{K}_{\mathrm{PG}}\right)}{1-0.64 \cdot\left(\mathrm{K}_{\mathrm{R}} / \mathrm{K}_{\mathrm{PG}}\right)}$ 
The initial secant stiffness of piles $\left(K_{P G}\right)$ and rafts $\left(K_{R}\right)$ can be expressed using the equation by Poulos \& Davis (1980):

$$
\begin{aligned}
& \mathrm{K}_{\mathrm{PG}}=\mathrm{K}_{\mathrm{PG}, \mathrm{i}} \cdot\left(1-\mathrm{R}_{\mathrm{PG}} \cdot \frac{\mathrm{P}_{\mathrm{PG}}}{\mathrm{P}_{\mathrm{PG}, \mathrm{ult}}}\right) \\
& \mathrm{K}_{\mathrm{R}}=\mathrm{K}_{\mathrm{R}, \mathrm{i}} \cdot\left(1-\mathrm{R}_{\mathrm{R}} \cdot \frac{\mathrm{P}_{\mathrm{R}}}{\mathrm{P}_{\mathrm{R}, \mathrm{ult}}}\right)
\end{aligned}
$$

Where: $K_{P G, i}$ and $K_{R, i}$ are the initial tangent stiffness of the piles group and of the raft, respectively. Fleming et al. (1992) propose that $K_{P G, i}$ can be obtained directly through the graph of the load-settlement curve or through Eq. (7). $R_{P G}$ and $R_{R}$ are hyperbolic factors equivalent to 0.5 and 0.75 , respectively (Poulos 2000). $P_{P G}$ and $P_{R}$ are the loads born by the piles group and raft, respectively, and $\mathrm{P}_{\mathrm{PG}, \mathrm{ult}}$ and $\mathrm{P}_{\mathrm{R} \text {,ult }}$ are the ultimate loads.

\section{EXPERIMENTAL TESTS}

Both experimental field and laboratory models were developed aiming to clarify the behaviour of pile groups subject to compression load as well as the load transfer mechanism in depth.

The fied experimental part of this study was developed at Unicamp Experimental Site II, located near the School of Civil Engineering, Architecture and Urban Planning (FEC) of Unicamp, in Campinas, SP, Brazil, in a region that includes basic intrusive rocks of the Serra Geral formation (Diabase) of the São Bento Group (Figure 4). Considering a pedological analysis, soils of this region can be classified as purple latosols, mineralogically consisting of quartz, ilmenite, magnetite, kaolinite, gibbsite, iron oxides and hydroxides; the thickness of this layer ranges from 5 to 30 m (Zuquette 1987), with an unsaturated, porous and collapsible surface zone.

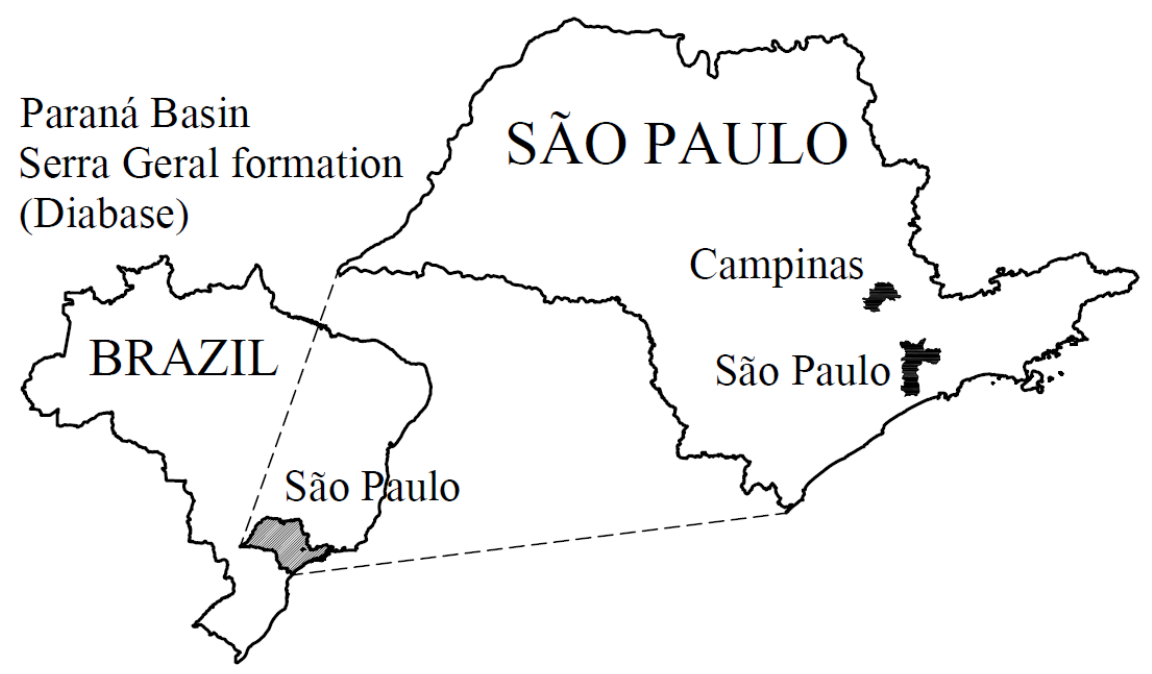

Figure 4: Location of the city of Campinas (Garcia \& Albuquerque 2018)

The geological-geotechnical profile, and the mean parameters for each soil layer were previously obtained through laboratory tests conducted by Gon (2011). The mean parameters for the layers were obtained through SPT and CPT tests. The results for the characterization stage of the subsurface in relation to the analyzed piled raft foundations enabled the elaboration of the geological-geotechnical profile of the local subsurface and the identification of the position of the block and piles that are grounded on the sandy silt layer at $2.35 \mathrm{~m}$ above the clayey sand layer (Figure 5). 


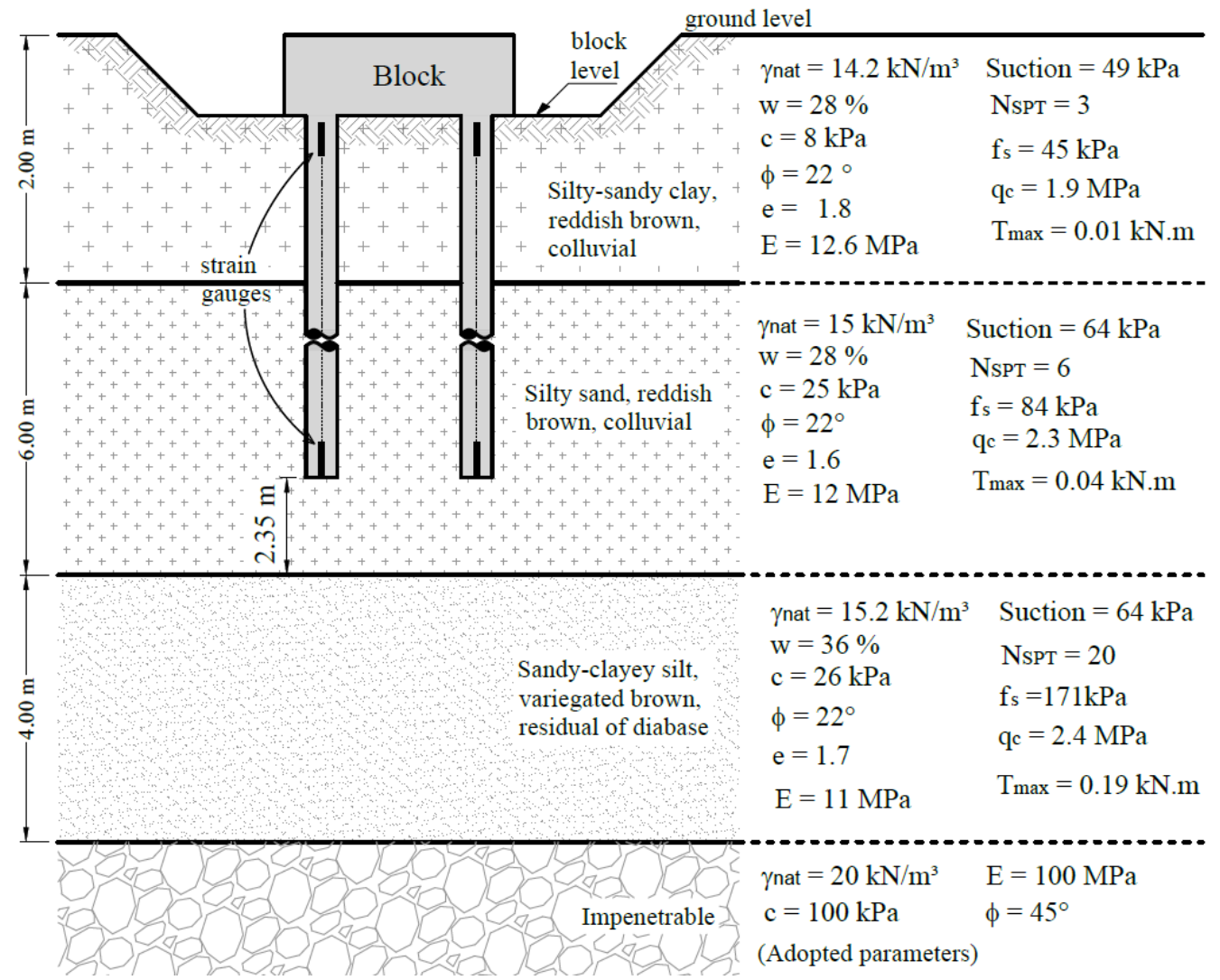

Figure 5: Geological-geotechnical profile and position of the piled rafts 4 Piled foundation blocks

Sets of blocks of one, two, three and four bored piles with diameter of $0.25 \mathrm{~m}$ and length of $5 \mathrm{~m}$ each were performed at the experimental site. All piles were instrumented with strain-gauges placed on the top and the tip of the studied piles. The instrumentation was installed as a complete bridge circuit on a $0.6 \mathrm{~m}$ length steel bar with diameter of $12.5 \mathrm{~mm}$ (Figure $6 \mathrm{a}$ and $6 \mathrm{~b}$ ). These bars were attached to the center of the pile reinforcement on the top a tip position. Figure 6 also presents information regarding the position of beams instrumented with strain gauges to evaluate load transfer.

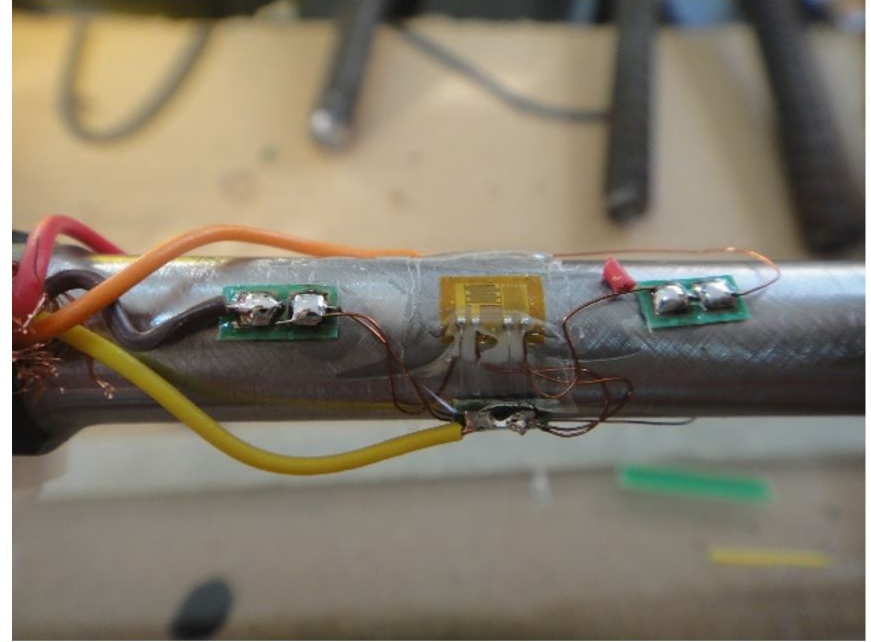

a) Connexion detail

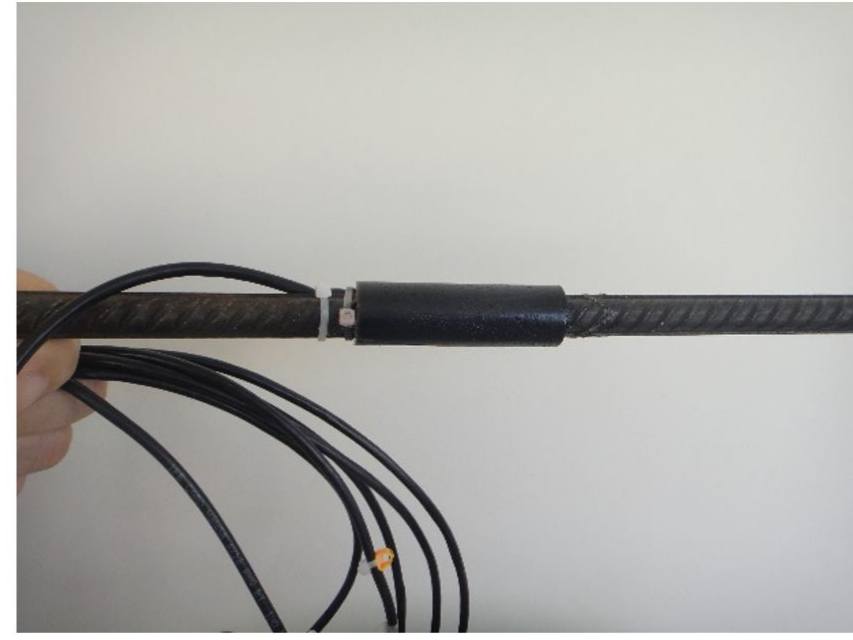

b) Instrumented bar

Figure 6: Instrumentation details

The piled raft foundation blocks were made using one, two, three and four piles, structurally dimensioned using the software CYPECAD (version 2015.n), as elements with a compression rod inclination angle $(\theta)$ of between $40^{\circ}$ and $55^{\circ}$. 
The space adopted between piles was five times their diameter $(5 \phi)$ to ensure a larger contact area between the block and ground, thus achieving a similar behavior to piled raft behavior. The geometrically tested piled foundations, the placement of the piles of each piled block and the relationships between the areas are shown in Table 1 and Figure 7.

Table 1: Geometric characteristics of piled foundations

\begin{tabular}{|c|c|c|c|c|c|c|}
\hline Piled Foundation & $\begin{array}{c}\text { Number of } \\
\text { piles [-] }\end{array}$ & $\begin{array}{c}\text { Pile area } \\
\left(\mathrm{A}_{\text {pile }}\right)\left[\mathrm{m}^{2}\right]\end{array}$ & $\begin{array}{l}\text { Block area } \\
\left(\mathrm{A}_{\text {total }}\right)\left[\mathrm{m}^{2}\right]\end{array}$ & $\begin{array}{l}\text { Net area } \\
\left(\mathrm{A}_{\text {net }}\right)\left[\mathrm{m}^{2}\right]\end{array}$ & $\begin{array}{c}\text { relation } \\
\mathbf{A}_{\text {net }} / \mathbf{A}_{\text {piles }}\end{array}$ & $\begin{array}{c}\text { Rod angle } \\
{\left[^{\circ}\right]}\end{array}$ \\
\hline 1 pile & 1 & 0.0491 & 0.36 & 0.31 & 6.31 & 41.28 \\
\hline 2 piles & 2 & 0.0982 & 1.11 & 1.01 & 10.29 & 41.28 \\
\hline 3 piles & 3 & 0.1473 & 2.03 & 1.88 & 12.76 & 44.29 \\
\hline 4 piles & 4 & 0.1964 & 3.42 & 3.22 & 16.40 & 49.50 \\
\hline
\end{tabular}
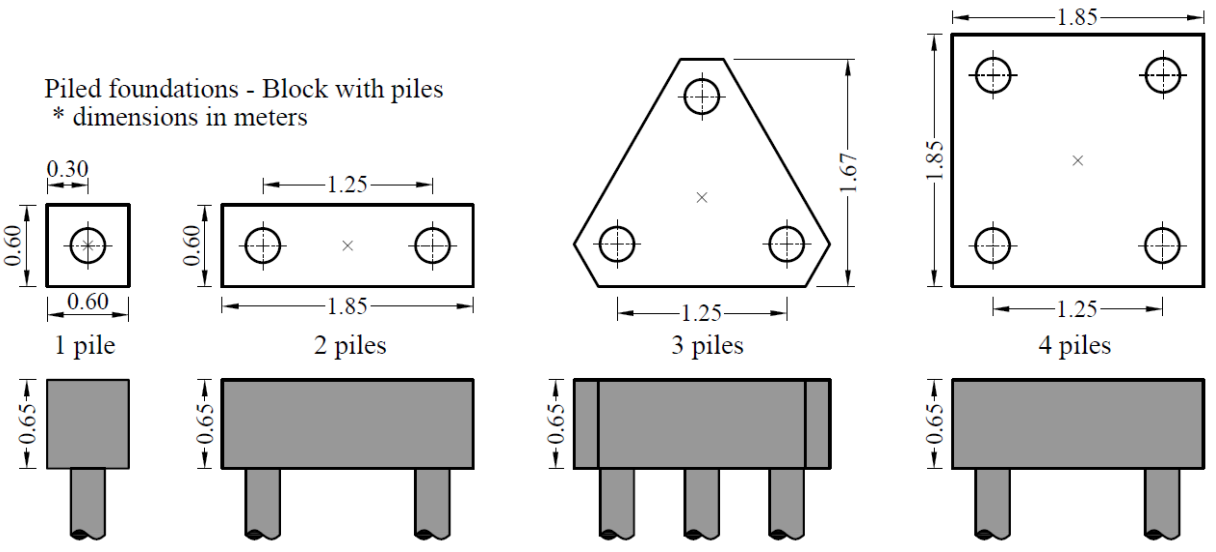

Figure 7: Plan view and elevation details of piled foundations

The piled blocks were executed on excavations made directly on the soil mass, then, the sides of these blocks were dug to free them from lateral contact with the soil (Figure 8).

a)

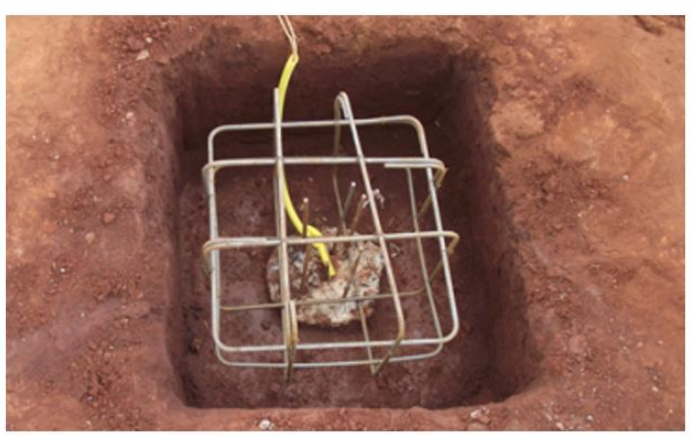

c)

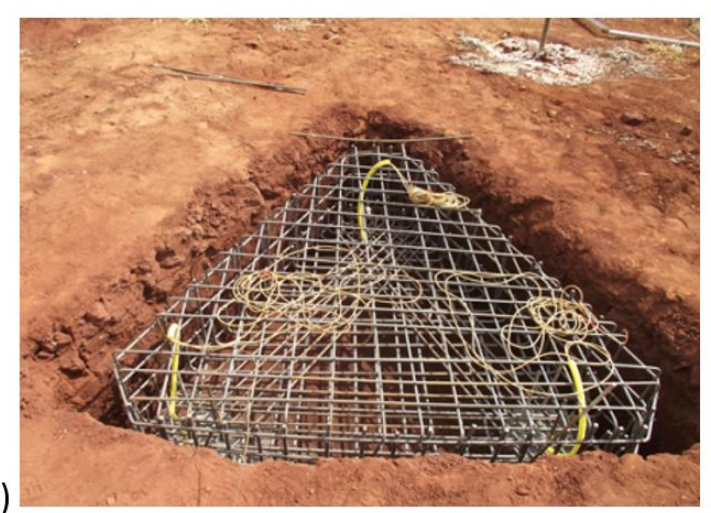

b)

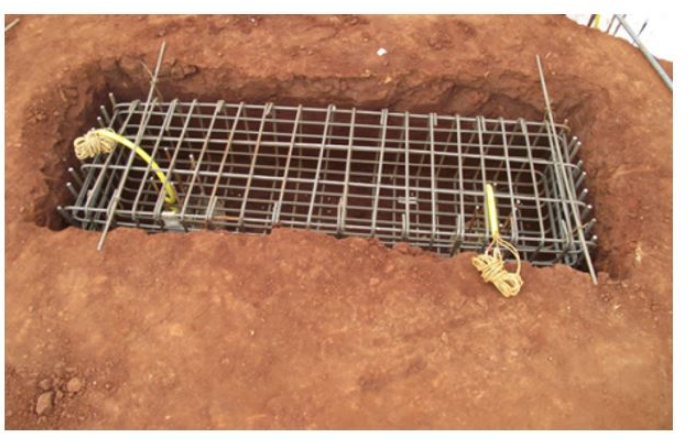

d)

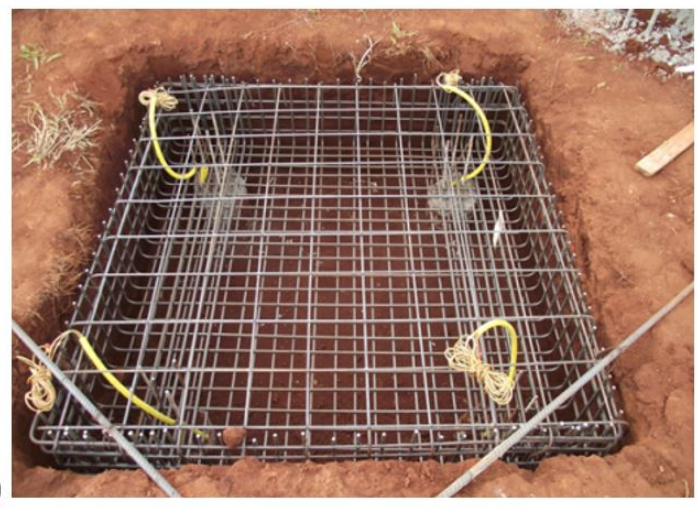

Figure 8: Details of the piled blocks construction 
Test specimens were molded during the execution of the piled blocks for technological control of simple compressive strength, determination of the elasticity modulus and Poisson's coefficient $\left(v=\varepsilon_{\mathrm{r}} / \varepsilon_{\mathrm{v}}\right)$ of concrete used, since the blocks were equipped with strain-gauges ( $30 \mathrm{~mm}$ length) to measure radial ( $\left.\varepsilon_{\mathrm{r}}\right)$ and vertical deformation ( $\varepsilon_{\mathrm{v}}$ ) (Figure 9a). All piles and blocks were filled with the same type of concrete.

All test specimens $(\mathrm{L}=20 \mathrm{~cm}$ and $\varphi=10 \mathrm{~cm}$ ) were prepared in the field according to NBR 5738 (ABNT 2015) at the same time the piles and blocks were filled with concrete. Afterwards they were taken to the concrete laboratory to remain under water for a 28-day curing period before the compressive strength test according to NBR 5739 (ABNT 2018) (Figure 9b).
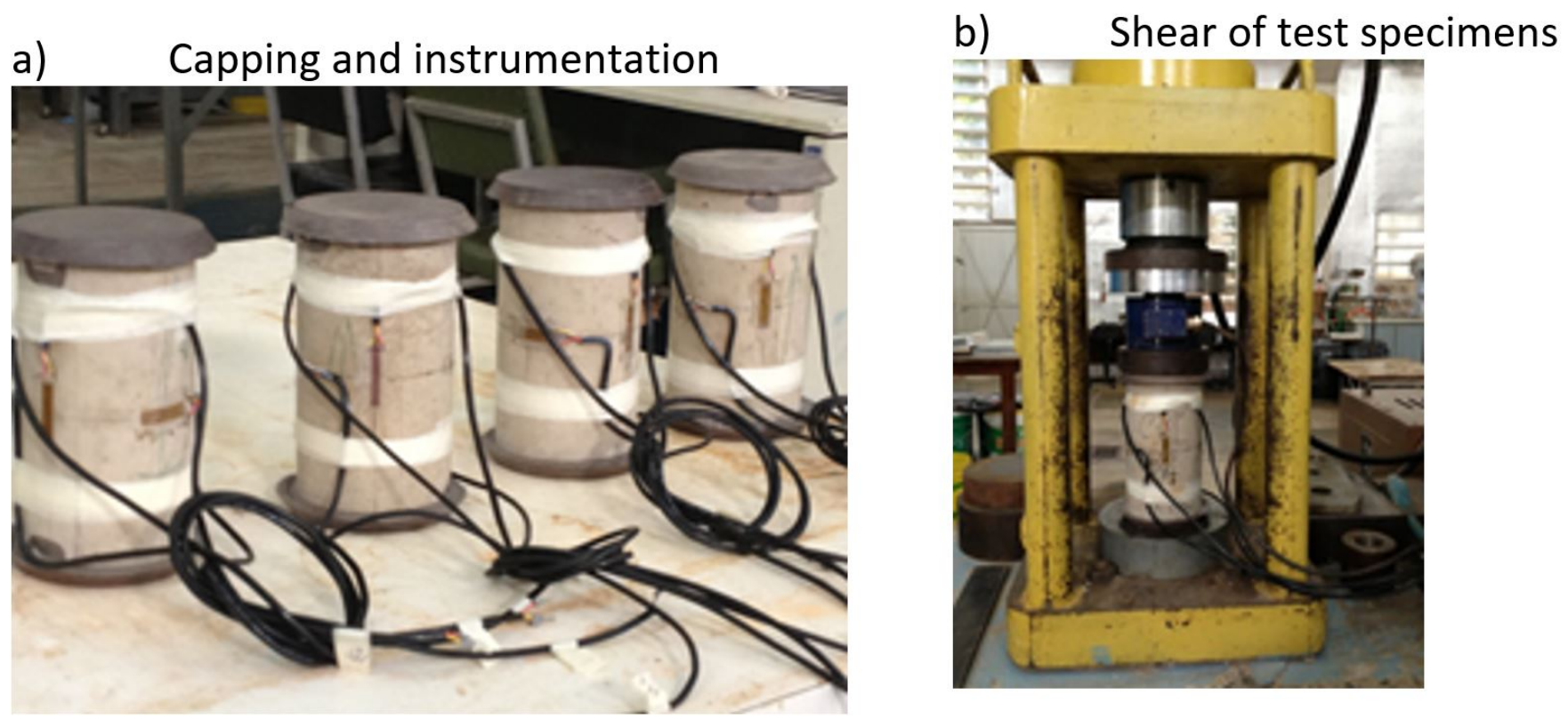

Figure 9: Technological control of the block and pile concrete.

Stress vs strain graphs were obtained through the results from the concrete strength tests (Figure 10). Both concrete and steel Young modulus previously obtained were used to estimate the composite modulus. This is proportional value of the structural elements, block and pile (Eq. 2). The values resulting from the shear to compression and its deformability modulus were obtained for five specimens tested, as shown in Table 2.

$E_{\text {composite }}=\frac{A_{a} \cdot E_{a}+A_{c} \cdot E_{c}}{A_{a}+A_{c}}$

Where: $A_{a}$ - useful cross-sectional area of steel; $E_{a}$ - elastic modulus of steel $\left(\mathrm{MN} / \mathrm{m}^{2}\right) ; A_{c}-$ useful cross-sectional area of concrete; $E_{c}$ - elastic modulus of concrete $\left(\mathrm{MN} / \mathrm{m}^{2}\right)$. 


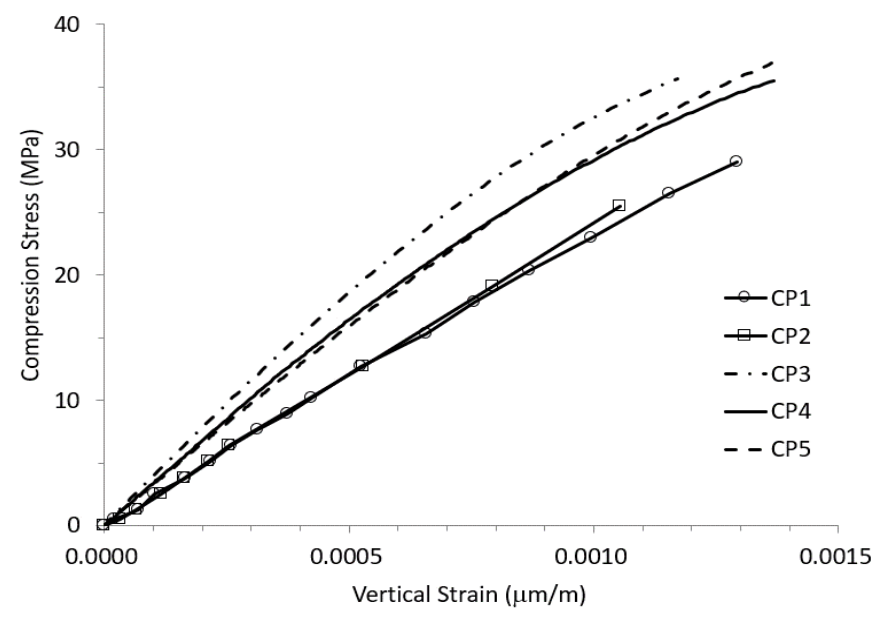

Figure 10: Stress vs strain curves.

Table 2: Simple compressive strength and elastic modulus of concrete

\begin{tabular}{|c|c|c|}
\hline \multirow[t]{2}{*}{ Test specimens } & $\begin{array}{l}\begin{array}{l}\text { Rupture strength to simple compressive } \\
\text { test }\end{array} \\
\end{array}$ & Initial tangent elastic modulus \\
\hline & [MPa] & [GPa] \\
\hline $\mathrm{CP} 1$ & 34.9 & 22.3 \\
\hline $\mathrm{CP} 2$ & 25.5 & 24.3 \\
\hline $\mathrm{CP} 3$ & 40.0 & 32.2 \\
\hline $\mathrm{CP} 4$ & 39.2 & 28.1 \\
\hline CP5 & 43.7 & 26.9 \\
\hline Average & 36.7 & 26.8 \\
\hline Standard deviation & 6.24 & 3.39 \\
\hline Coefficient of variation (\%) & 17.0 & 12.7 \\
\hline
\end{tabular}

As the full bridge circuit with four active strain-gauges was used in this study, effects of temperature and bending strains were eliminated. As result, only strains from normal resistance were obtained. The operational principle consists on a strain $(\varepsilon)$ caused in a section of the pile area $(A)$ due to certain loading. This strain is obtained by an electrical resistance extensometer (strain-gauge). According to Hooke's Law (Eq. 16):

$\mathrm{P}=\mathrm{E}_{\text {composite }} \cdot \mathrm{A} \cdot \varepsilon$

Where:

$\mathrm{P}=$ Load in the cross section

$\mathrm{E}_{\text {composite }}=$ Pile elasticity modulus

$A=-$ Area of the pile cross section

$\varepsilon=$ Strain measured

To determine the load transfer along the pile, the data from the instrumentation were analysed. By using both Hooke's theory and the elasticity modulus of the materials, the loads of each instrumented level were obtained.

The load test system consisted of bored piles $((\varphi=0.6 \mathrm{~m}$ and $\mathrm{L}=9.0 \mathrm{~m})$ designed to resist the tensile stresses caused by the reaction of the system during the load tests. The piles were reinforced with $10 \mathrm{CA}-50 \mathrm{steel}$ bars $(\varphi=10 \mathrm{~mm})$ and CA-50 steel helical stirrups $(\varphi=6.3 \mathrm{~mm})$. This reinforcement was completed by installing a Dywidag tie rod with a $9 \mathrm{~m}$ length and diameter of $32 \mathrm{~mm}$. The reaction beam used in the load tests was $5.3 \mathrm{~m}$ long and formed by the welding of two I-beams capable of resisting up to $2 \mathrm{MN}$ (Figure 11).

A load cell with a maximum capacity of $2 \mathrm{MN}$ was used for the load measurement on the top of the block. In order to obtain the displacement data, four transducers $(L=100 \mathrm{~mm})$ were installed diagonally on the top of this block. 

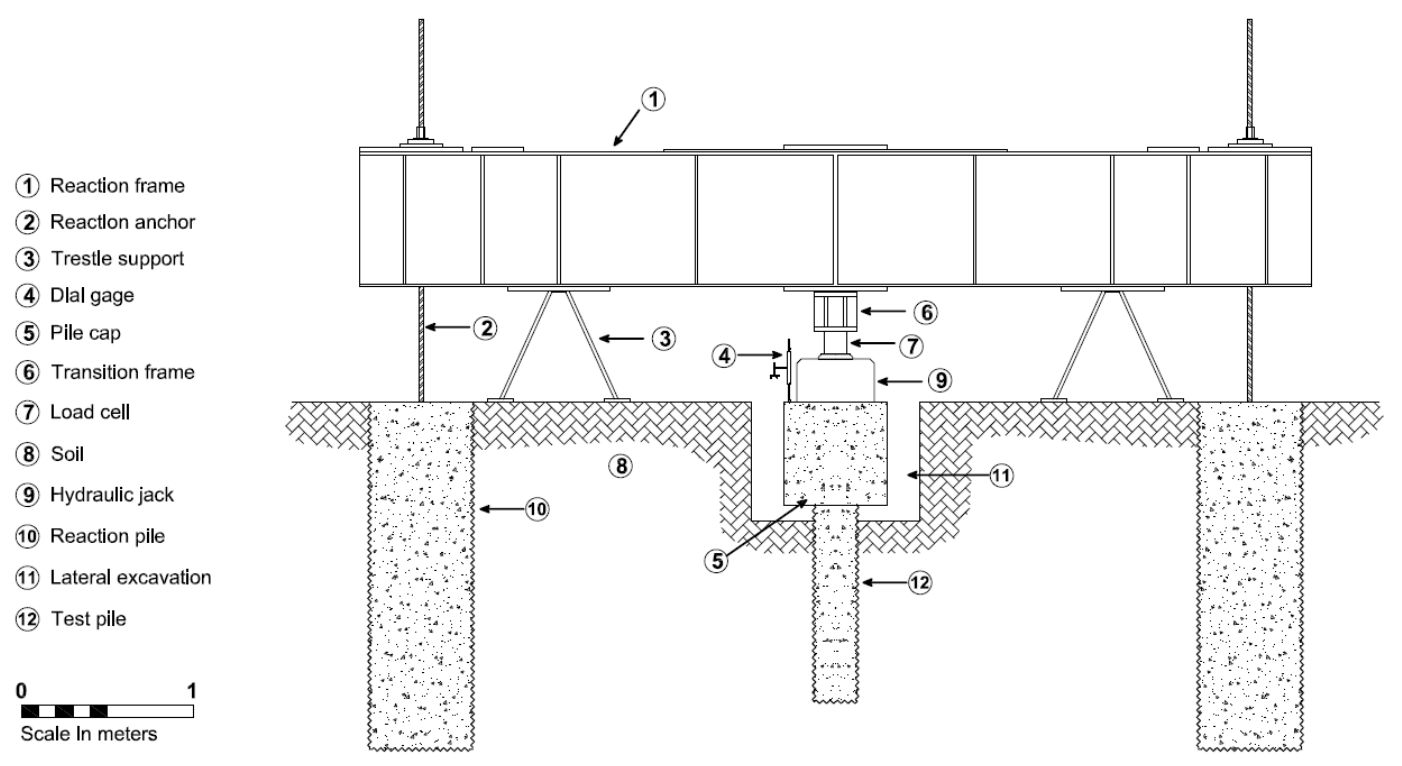

Figure 11: Front view sketch of the main reaction system (Garcia, 2015).

\section{RESULTS AND DISCUSSION}

The pile groups were subjected to slow-maintained load test (SMLT) according to NBR 12.131 (ABNT 2006). Foundation elements were loaded until a displacement that characterized a non-stop displacement for the ultimate load, obtaining values over $40 \mathrm{~mm}$.

\subsection{Load-settlement curves}

Load-settlement curves were obtained from the tests (Figure 12 and Table 3). Load proof tests were conducted in ten consecutive stages and plotted considering the reduction of the relationship $Q_{\max } / Q$ and the load-settlement curves to better understand the behavior (Figure 13).

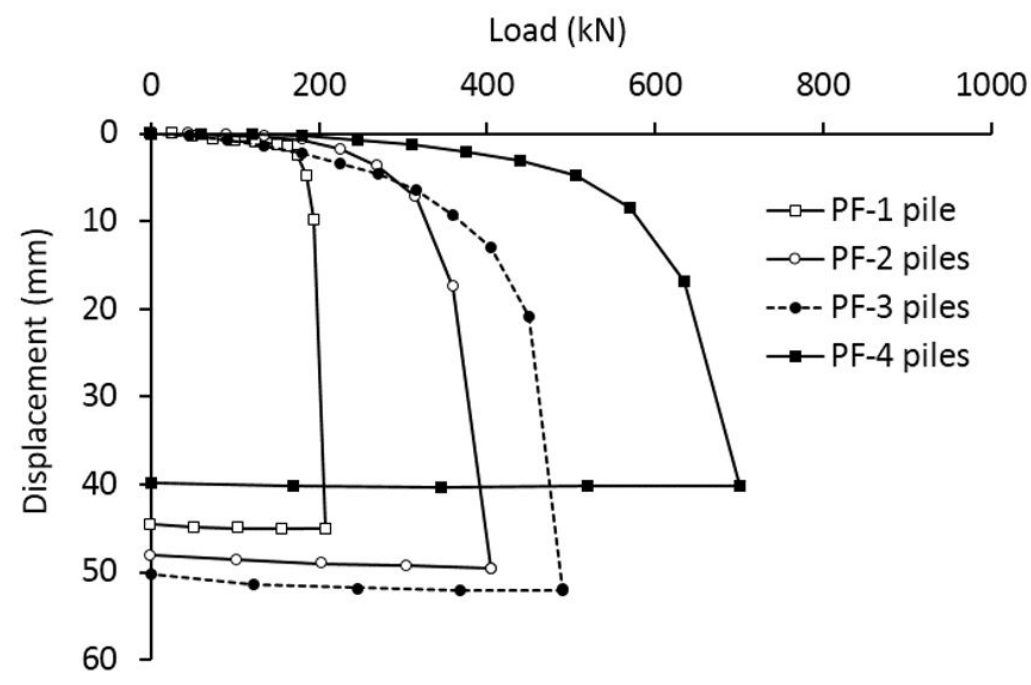

Figure 12: Results for load-displacement curve of piled foundations. 


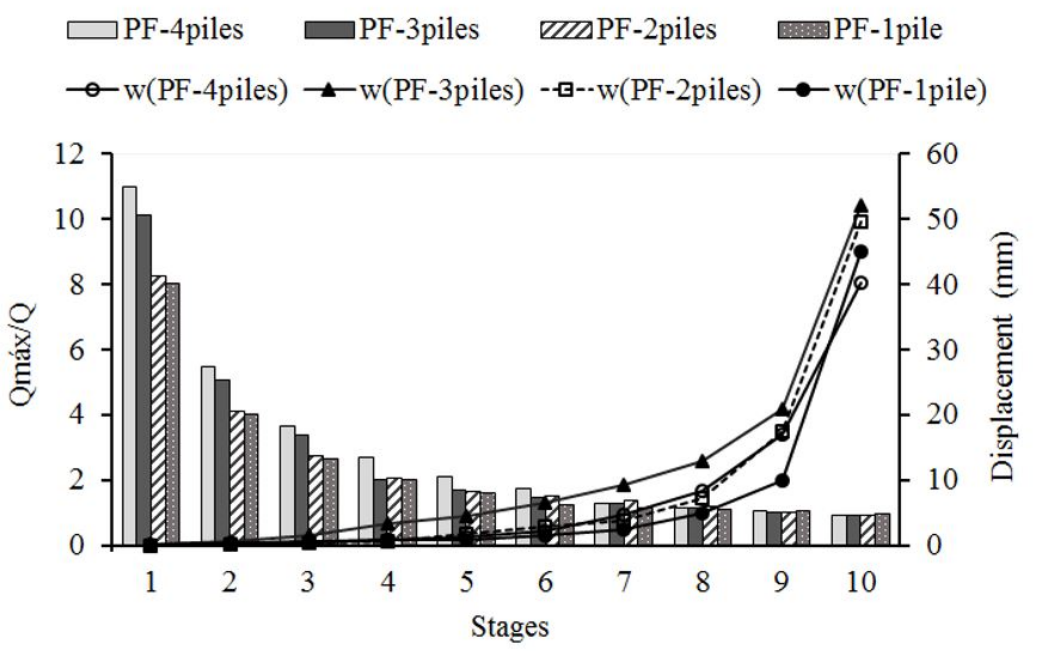

Figure 13: Variation of the $Q / Q$ max relationship by stage increment and displacement.

Table 3: Load tests details

\begin{tabular}{ccccccc}
\hline Load test & Date & Foundation type & $\begin{array}{c}\text { Number of } \\
\text { stages }\end{array}$ & $\begin{array}{c}\text { Maximum load } \\
\mathbf{( k N )}\end{array}$ & $\begin{array}{c}\text { Load increment } \\
\text { (kN) }\end{array}$ & $\begin{array}{c}\text { Maximum } \\
\text { settlement } \\
(\mathbf{m m})\end{array}$ \\
\hline 1 & $16 / 10 / 2012$ & PF-1pile & 10 & 208 & 20 & 45.09 \\
2 & $30 / 10 / 2012$ & PF-2piles & 10 & 405 & 40 & 49.61 \\
3 & $31 / 10 / 2012$ & PF-3piles & 10 & 490 & 50 & 52.02 \\
4 & $18 / 11 / 2012$ & PF-4piles & 10 & 700 & 65 & 40.14 \\
\hline
\end{tabular}

The allowable load was established in relation to the last load obtained by applying a safety factor equal to 2 (Table 4). Analyses were made to determine the last load employing Van der Veen's (1953) methods and Stiffness (Décourt, 2008). Van der Veen's (1953) method presented results near the maximum load values of the load proof, representing a possible overestimation in the definition of shear load values. On the other hand, the Stiffness (Décourt, 2008) method showed shear load values $3 \%$ to $12 \%$ lower in relation to the maximum load values of the load proof, except for the block using one pile, which presented an ultimate load estimation that was slightly higher than maximum. Considering the coherence between the obtained results (Table 4), the ultimate loads obtained through the Stiffness method were chosen to be adopted in the load capacity analyses. Thus, the criteria defined by Eurocode 7 (2004) was used, which assumes the shear load as the result from a $10 \%$ displacement on the pile on the load-settlement curve (Figure 14 to Figure 17)

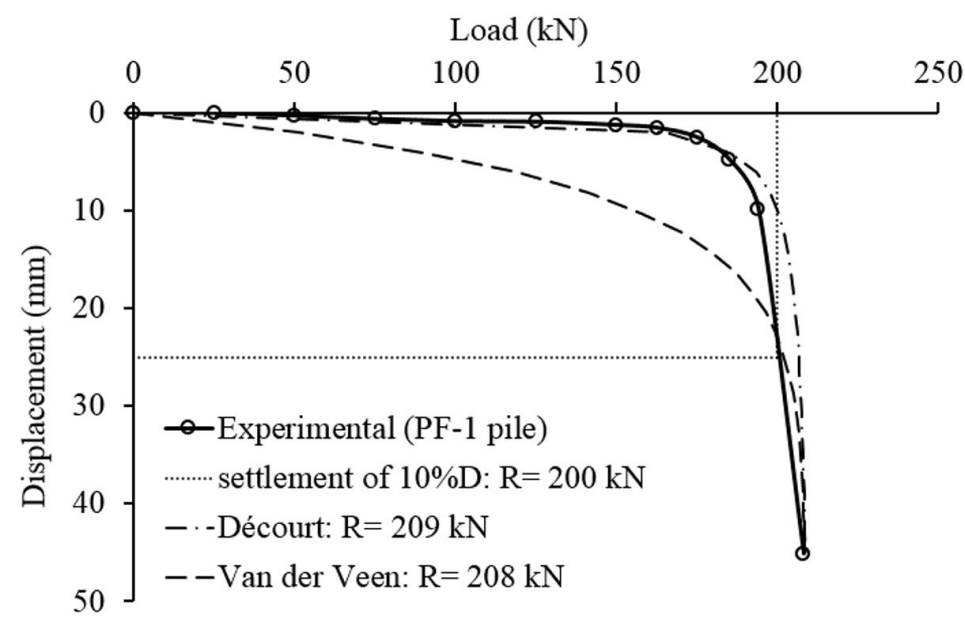

Figure 14: Extrapolation of the curve for the piled raft using one pile. 


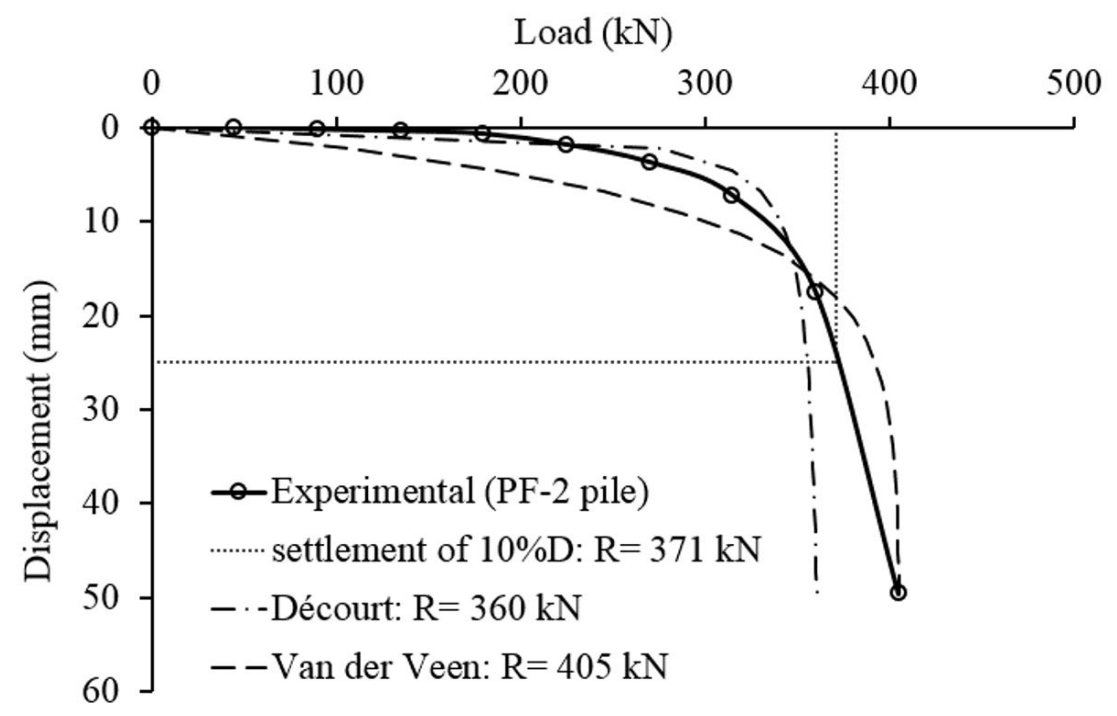

Figure 15: Extrapolation of the curve for the piled raft using two piles.

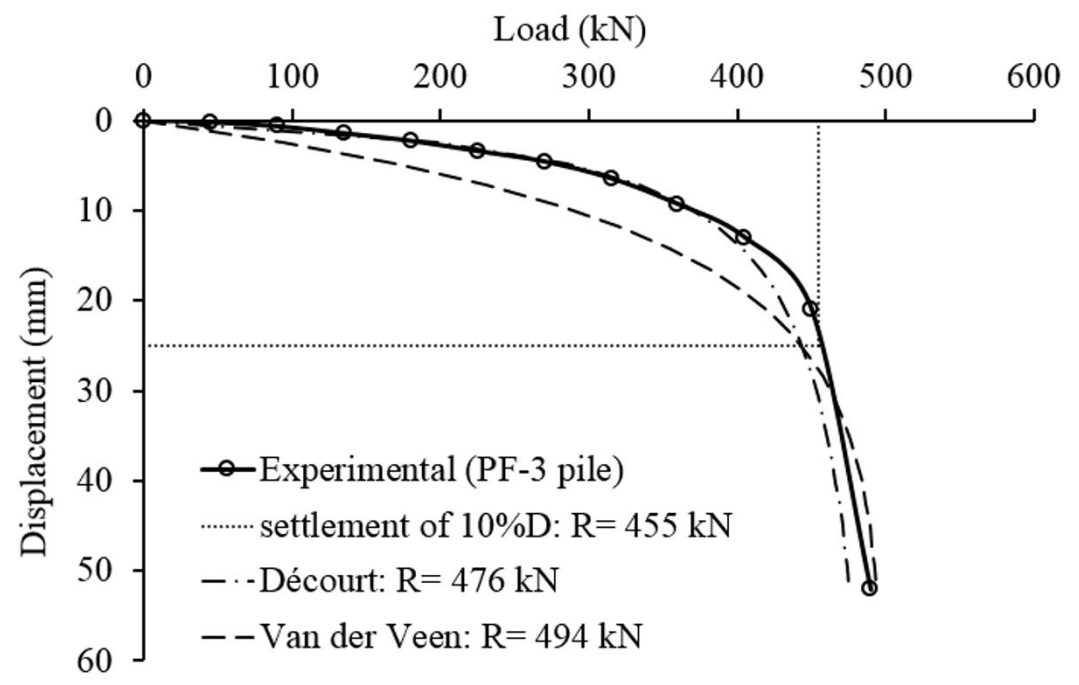

Figure 16: Extrapolation of the curve for the piled raft using three piles.

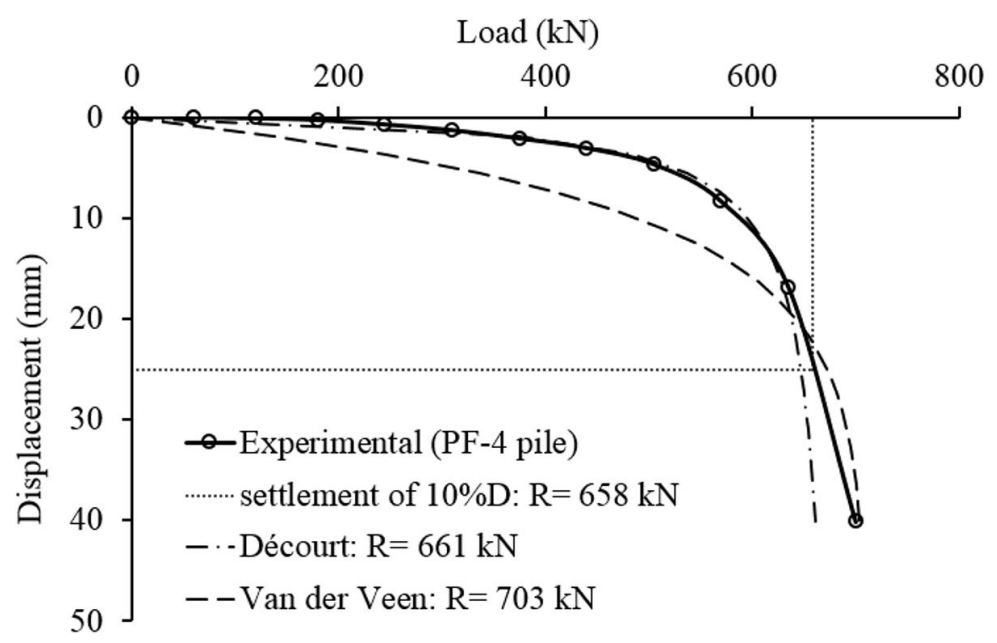

Figure 17: Extrapolation of the curve for the piled raft using four piles. 
Table 4: Extrapolated failure load (R), maximum settlement load (Pmax), load corresponding to the $10 \%$ settlement $\varphi(\mathrm{P} 10 \%)$ and allowable foundation loads (Pal) via distinct failure criteria.

\begin{tabular}{|c|c|c|c|c|c|c|}
\hline \multirow{2}{*}{ Piled Foundation } & \multicolumn{2}{|c|}{ Van der Veen } & \multicolumn{2}{|c|}{ Stiffness } & \multicolumn{2}{|c|}{$10 \% \cdot \varphi$} \\
\hline & $R(k N)$ & $P_{\mathrm{al}}(\mathrm{kN})$ & $\mathrm{R}(\mathrm{kN})$ & $\mathrm{P}_{\mathrm{al}}(\mathrm{kN})$ & $\mathbf{P}_{10 \%}(\mathbf{k N})$ & $P_{a l}(k N)$ \\
\hline 1 pile & 208 & 104.0 & 209 & 104.5 & 200 & 100.0 \\
\hline 2 piles & 405 & 202.5 & 360 & 180.0 & 371 & 185.5 \\
\hline 3 piles & 494 & 247.0 & 476 & 238.0 & 455 & 227.5 \\
\hline 4 piles & 703 & 351.5 & 661 & 330.5 & 658 & 329.0 \\
\hline
\end{tabular}

It can be observed that the allowable load values obtained through Van der Veen's method are superior to those obtained through the Stiffness method. On the other hand, Stiffness method values showed coherence, since the percentage differences found were $12 \%$ on average for foundations with two, three and four piles. For the foundation using one pile the difference was $30 \%$ (Table 5). Settlement values obtained from the allowable loads do not exceed limit values recommended by Terzaghi et al. (1996).

Table 5: Allowable loads of tests and equivalent settlements via distinct failure criteria.

\begin{tabular}{|c|c|c|c|c|c|c|}
\hline \multirow{2}{*}{ Piled Foundation } & \multicolumn{2}{|c|}{ Van der Veen } & \multicolumn{2}{|c|}{ Décourt } & \multicolumn{2}{|c|}{$10 \% \cdot \varphi$} \\
\hline & $\mathrm{P}_{\mathrm{al}}(\mathrm{kN})$ & $\rho(\mathrm{mm})$ & $P_{\mathrm{al}}(\mathrm{kN})$ & $\rho(\mathrm{mm})$ & $P_{\mathrm{al}}(\mathrm{kN})$ & $\rho(\mathrm{mm})$ \\
\hline 1 pile & 104.0 & 5.1 & 104.5 & 1.3 & 100.0 & 0.9 \\
\hline 2 piles & 202.5 & 5.1 & 180.0 & 1.5 & 185.5 & 1.3 \\
\hline 3 piles & 247.0 & 7.9 & 238.0 & 3.5 & 227.5 & 4.0 \\
\hline 4 piles & 351.5 & 5.9 & 330.5 & 1.6 & 329.0 & 1.8 \\
\hline
\end{tabular}

Load distribution between foundations elements, both deep and shallow, that compose the piled raft were obtained through information from instruments placed on top of the piles, as seen in Figure 5. The loads were obtained applying the Equation 16 for each instrumented level (top and tip).

Table 6 shows the load distribution between the piled raft and piles. When analyzing these parameters, bearing capacity contribution of the shallow element varied from $15 \%$ (minimum) to $27 \%$ (maximum), whereas the load born by piles remained around $73 \%$ (minimum) and $85 \%$ (maximum). These percentage values were determined using the load bearing values by each element considering total load applied on the piled raft foundation.

Table 6: Load distribution between elements to the maximum settlement.

\begin{tabular}{|c|c|c|c|c|}
\hline \multirow{2}{*}{ Piled Foundation } & \multicolumn{2}{|l|}{$\mathbf{P}_{\mathrm{R}}$} & \multicolumn{2}{|l|}{$\mathbf{P}_{\mathrm{PG}}$} \\
\hline & $\%$ & (kN) & $\%$ & $(\mathrm{kN})$ \\
\hline 1 pile & 15 & 31 & 85 & 177 \\
\hline 2 piles & 27 & 111 & 73 & 294 \\
\hline 3 piles & 23 & 110 & 77 & 380 \\
\hline 4 piles & 21 & 149 & 79 & 551 \\
\hline
\end{tabular}

Note: $P_{R}$ is the load carried by contact raft and $P_{P G}$ is the load carried by pile group.

The efficiency of the pile group decreases as the number of interactions between piles increases (Table 7).

Table 7: Pile group efficiency $\left(\alpha_{\mathrm{PG}}\right)$ and block/raft efficiency $\left(\alpha_{R}\right)$

\begin{tabular}{|c|c|c|c|c|c|c|}
\hline \multirow{2}{*}{ Piled Foundation } & \multicolumn{3}{|c|}{ Pile group load (kN) } & \multicolumn{3}{|c|}{ Raft load (kN) } \\
\hline & Combined & Isolated & $\alpha_{P G}$ & Combined & Isolated & $\alpha_{R}$ \\
\hline PF - 1 pile & 177.3 & 208 & 0.85 & 31 & $34^{*}$ & 0.91 \\
\hline PF -2 piles & 294.4 & 405 & 0.73 & 111 & $123^{*}$ & 0.90 \\
\hline PF -3 piles & 380.8 & 490 & 0.77 & 110 & $240 *$ & 0.46 \\
\hline$P F-4$ piles & 551.4 & 700 & 0.79 & 149 & $317^{*}$ & 0.47 \\
\hline
\end{tabular}

* values extrapolated from tests conducted on the test site. 
The load distribution for each element, in each load distribution stage, was obtained through the readings from the instruments placed on top of the piles over the shallow element (Figure 18 to Figure 21).

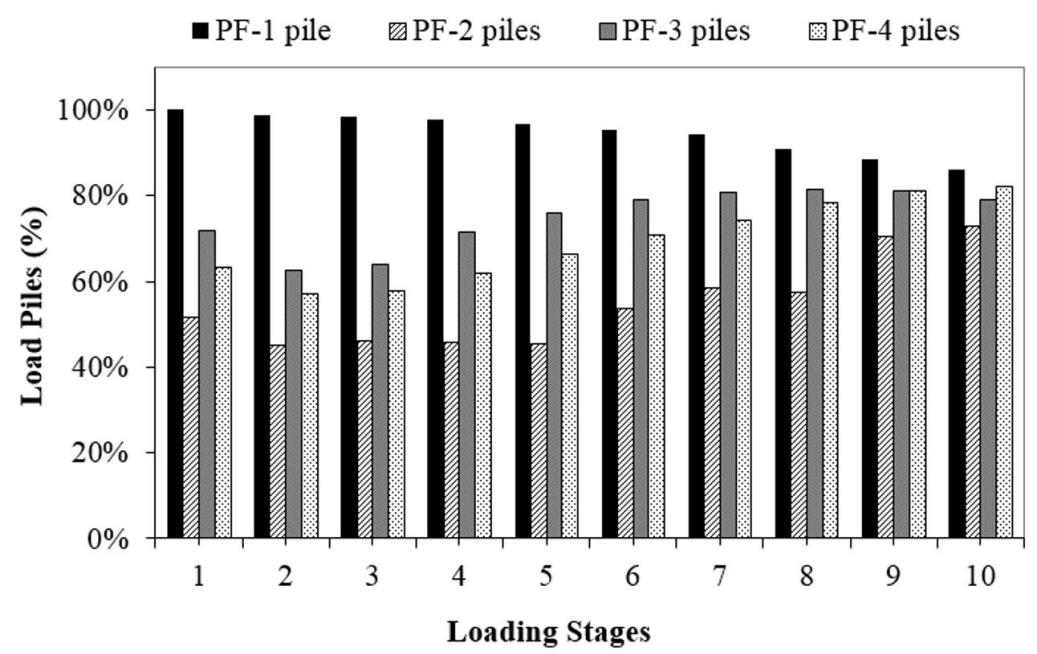

Figure 18: Load born by piles (lateral and tip strength).

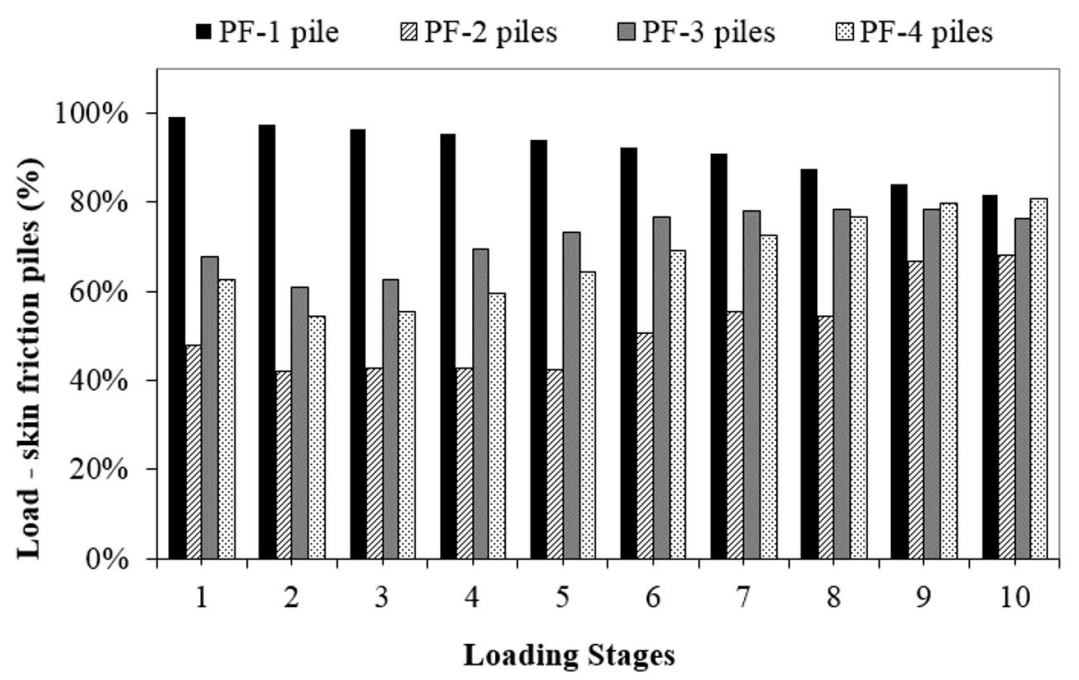

Figure 19: Load born by the lateral strength of piles.

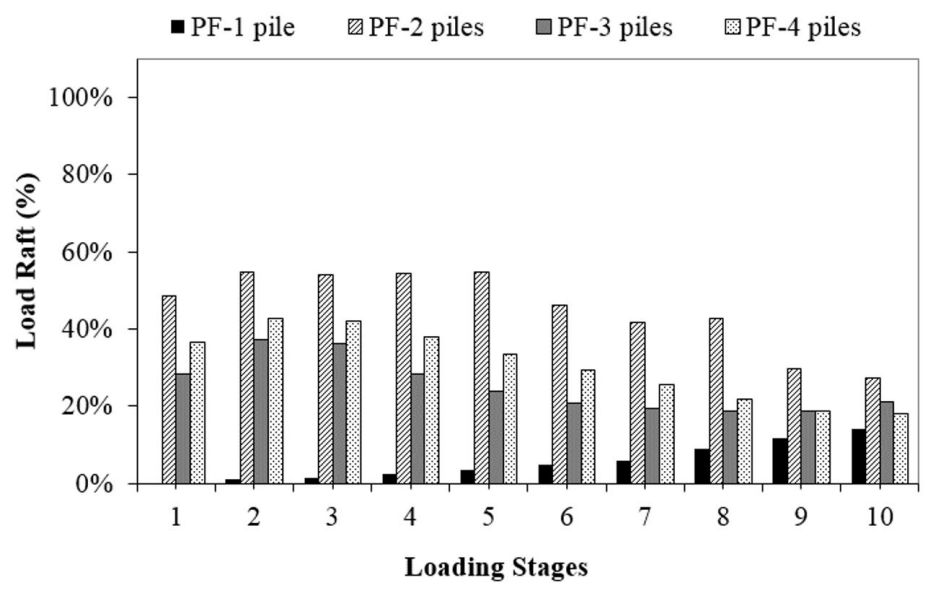

Figure 20: Load born by the contact of the shallow element. 


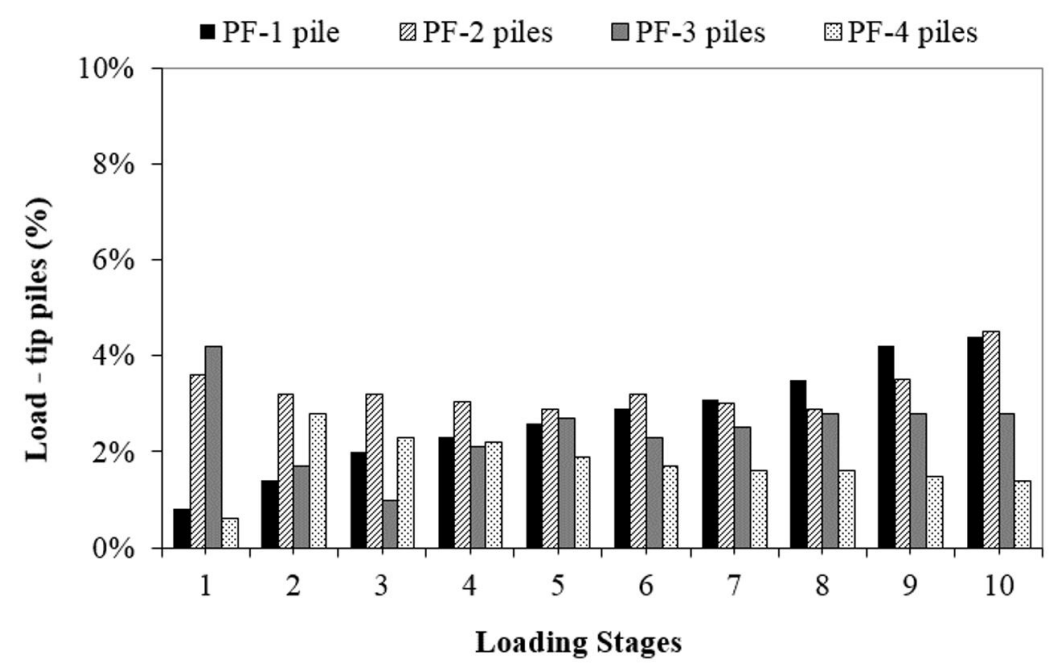

Figure 21: Load born by the tip strength of piles.

By analyzing the obtained data, it can be found that in groups of two, three and four piles, the initial loads applied on the piled foundation is born in $58 \%$ (average value) by pile groups; regarding the foundation composed of one pile,

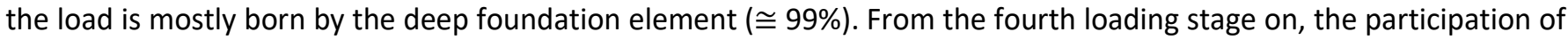
pile groups increases, considering that $78 \%$ of the total load applied on the piled foundation starts to be born by the piles and only $22 \%$ by the shallow foundation element (raft). According to the graph in Figure 19, the lateral friction of piles can be considered the main aspect responsible for the increase in pile group performance, with little tip strength participation being registered (Figure 20).

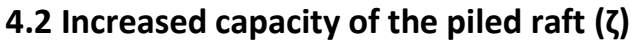

The gain in load capacity due to foundation contact with the ground is given by:

$\zeta_{P R}=\frac{Q_{P R}}{Q_{P G}}$

where $Q_{P R}$ is the bearing capacity of the piled raft and $Q_{P G}$ is that of the pile group.

From the results of the load-settlement curve of the analyzed foundations (Figure 14 e Figure 17), the corresponding maximum load value $\left(P_{\rho \max }\right)$ was applied to the maximum settlement $\left(\rho_{\max }=40 \mathrm{~mm}\right)$. The allowable load value was obtained for a 1.5 safety factor (Table 8). $\zeta_{\mathrm{PR}}$ values increase as the number of piles increases. This condition is consistent, as the number of piles enables an increment to the foundation load capacity. However, for the piled foundation of three piles, this factor was lower when compared to the one with two piles. In addition to the number of piles and the contact of the shallow foundation element, this fact may be influenced by triangle geometry of the three-piles piled raft.

Table 8: Bearing capacity increase

\begin{tabular}{cccc}
\hline Foundation & $\mathbf{P}_{\text {pmax }}(\mathbf{k N})$ & $\mathbf{P}_{\text {al }}(\mathbf{k N})$ & $\zeta_{\mathbf{P R}}$ \\
\hline 1-piled raft & 200 & 133.33 & 1.12 \\
2-piled raft & 371 & 247.33 & 1.26 \\
3-piled raft & 455 & 303.33 & 1.20 \\
4-piled raft & 658 & 438.66 & 1.29 \\
\hline
\end{tabular}

On the other hand, the points determined for piled foundations with three and four piles (Table 8) corroborate with the results from Conte et al. (2003) and Soares et al. (2015) obtained for $\xi_{P R}$ and $R_{M}$ indices in centrifuge tests in sandy soils (Figure 22). The piles placement under the piled raft is in accordance with the results of Conte et al. (2003) and Soares et al. (2015). The $\mathrm{R}_{\mathrm{M}}$ value shown in the graph in Figure 22, can be obtained through $R_{M}=R /\left(A_{G} / A\right)$, considering that $R=(n \cdot s / L)^{0.5}$, where $\mathrm{n}, \mathrm{s}$ and $\mathrm{L}$ represent number, spacing and length of piles, respectively. 


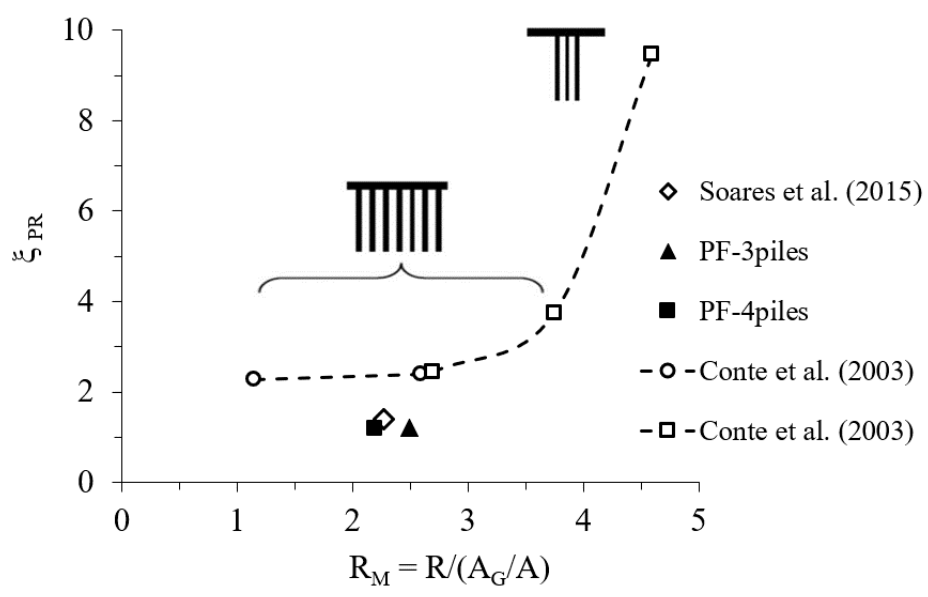

Figure 22: Comparison between the $\zeta_{P R}$ values of the foundations with 3 and 4 piles obtained in this study with the results from Conte et al. (2003) and Soares et al. (2015).

The results obtained in this study for piled raft foundations with two, three and four piles were in accordance with the $\alpha_{U R}$ factor of efficiency, when compared to those found by De Sanctis \& Mandolini (2006) and Soares et al. (2015), as shown in Figure 23.

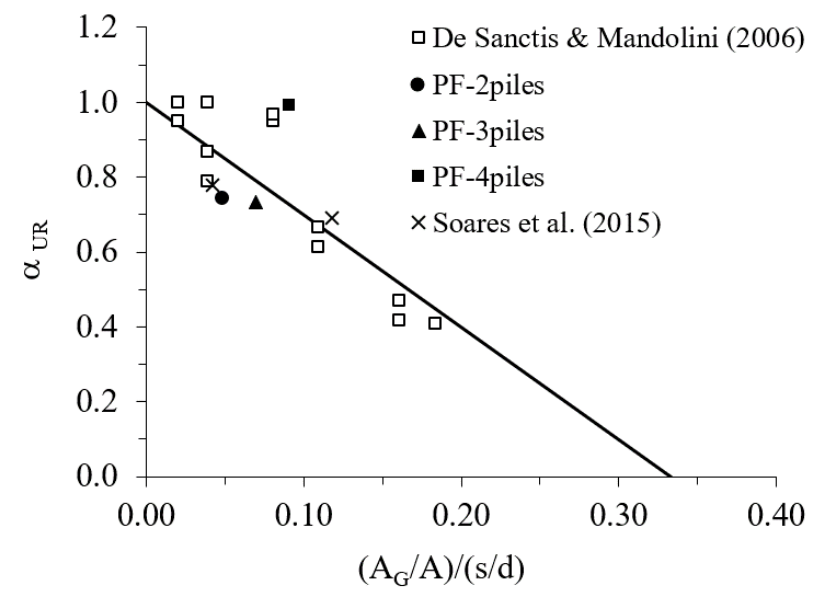

Figure 23: Comparison between $\alpha_{R}$ values of this research with results from Soares et al. (adapted from De Sanctis \& Mandolini 2006).

When comparing foundation elements separately and considering their displacement, it was found that in all piled raft foundations, the effect of shallow foundation element (raft) contact enabled an increase in the bearing capacity of the piled raft foundation (Figure 24 and Figure 27). For the foundation composed of a single pile, the shallow element only contributes with the bearing capacity from more severe displacements, i.e., the pile is the main element of the bearing capacity of the foundation system (Figure 24). This is evidenced by the overlap the load-displacement curves of the piled foundation and the pile until values near $150 \mathrm{kN}$.

Piled foundations with two, three and four piles present distinct load-displacement curves for piles, raft and piled foundation (piles and raft). For foundations with two and four piles and square or rectangular format, the curves of the different foundation elements overlap until approximately $100 \mathrm{kN}$. From this point on, the pile and raft loaddisplacement curves continue separately. The contribution from the raft is null or insignificant. The gain in load capacity starts to depend on pile strength (Figure 25 e Figure 27). The piled foundation with three piles shows increasing strength mobilization due to contact and piles, starting from the initial displacements. However, bearing capacity caused by contact only reaches the same value $(100 \mathrm{kN})$ of piled foundations with two and four piles. All bearing capacity is ruled by the pile strength and the increase in displacements (Figure 26). The initial stiffness or initial tangent obtained by the curves are shown in Figure 24 to Figure 27 and Table 9. 
Table 9: Stiffness of piles $\left(K_{p}\right)$, rafts $\left(K_{r}\right)$ and piled rafts $\left(K_{p r}\right)$.

\begin{tabular}{lccc}
\hline \multicolumn{1}{c}{ Foundation } & $\mathrm{K}_{\mathrm{P}}(\mathbf{k N} / \mathbf{m m})$ & $\mathrm{K}_{\mathrm{R}}(\mathbf{k N} / \mathbf{m m})$ & $\mathrm{K}_{\mathrm{PR}}(\mathbf{k N} / \mathbf{m m})$ \\
\hline Piled foundation -1 pile & 87 & 2 & 87 \\
Piled foundation -2 piles & 90 & 142 & 169 \\
Piled foundation -3 piles & 42 & 34 & 104 \\
Piled foundation -4 piles & 116 & 69 & 283 \\
\hline
\end{tabular}

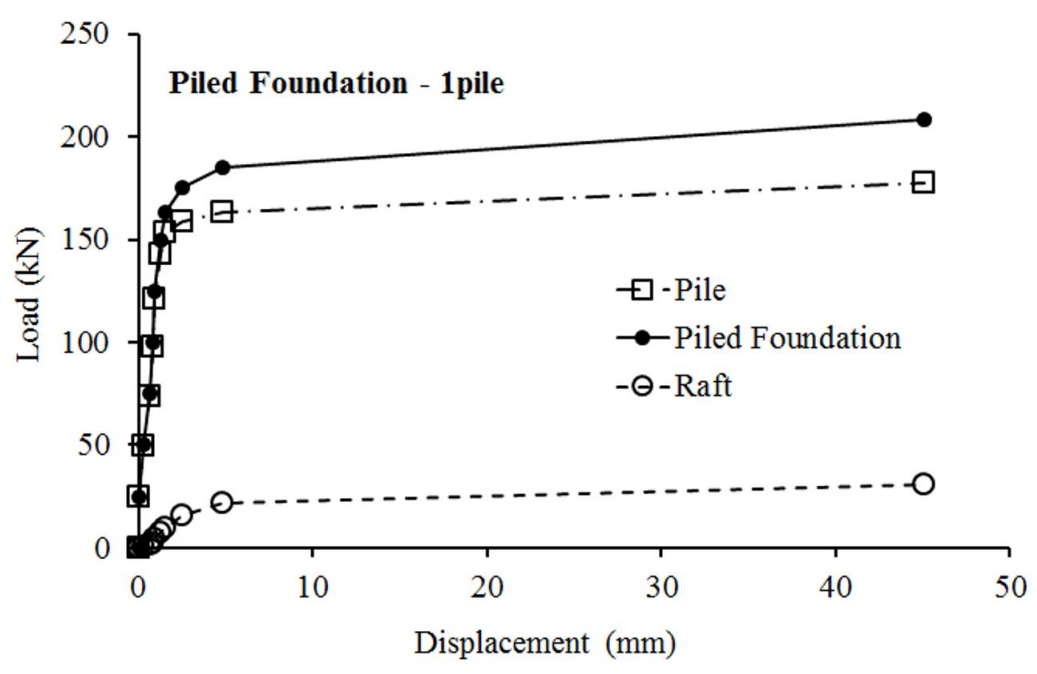

Figure 24: Load-displacement curve of piled foundation using one pile.

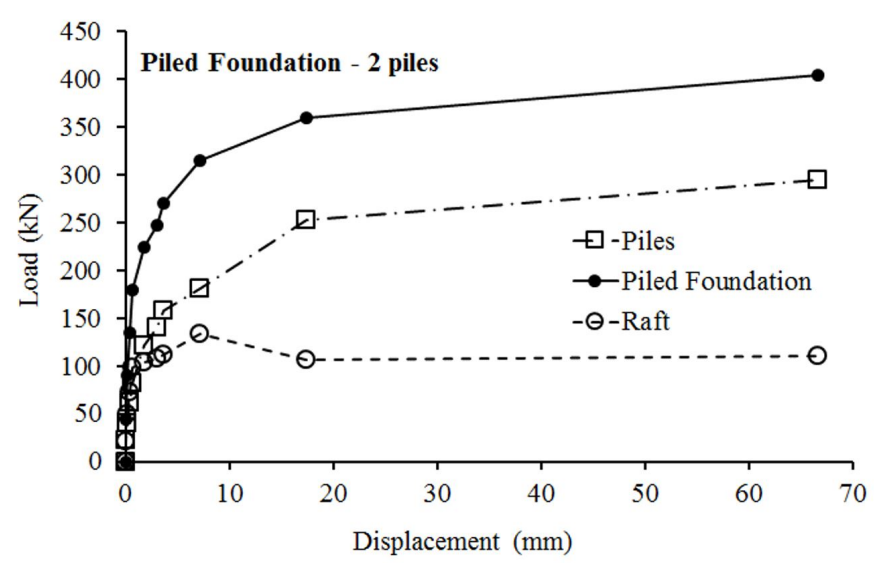

Figure 25: Load-displacement curve of piled foundation using two piles.

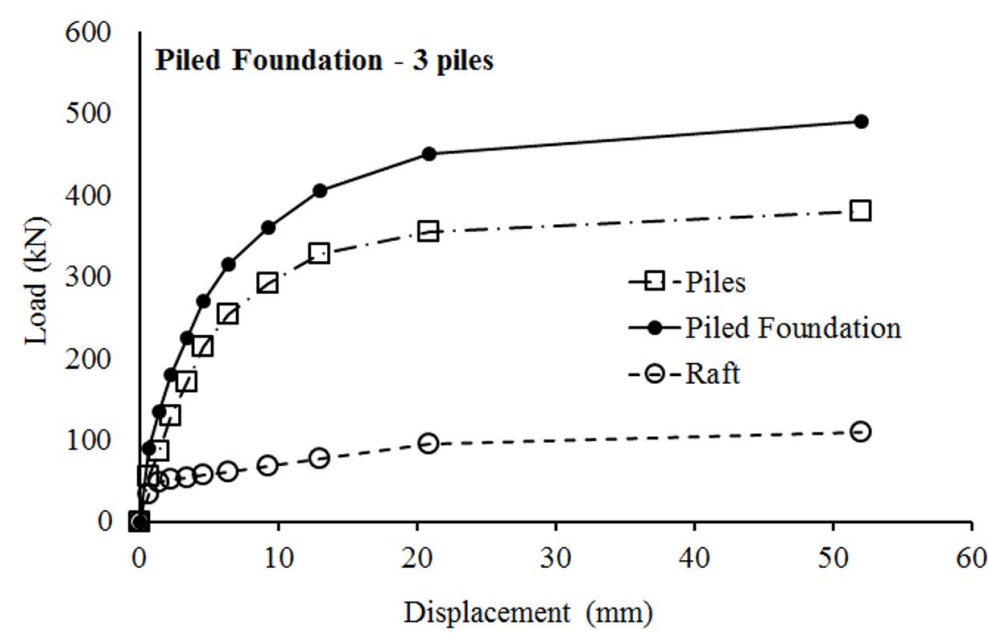

Figure 26: Load-displacement curve of piled foundation using three piles. 


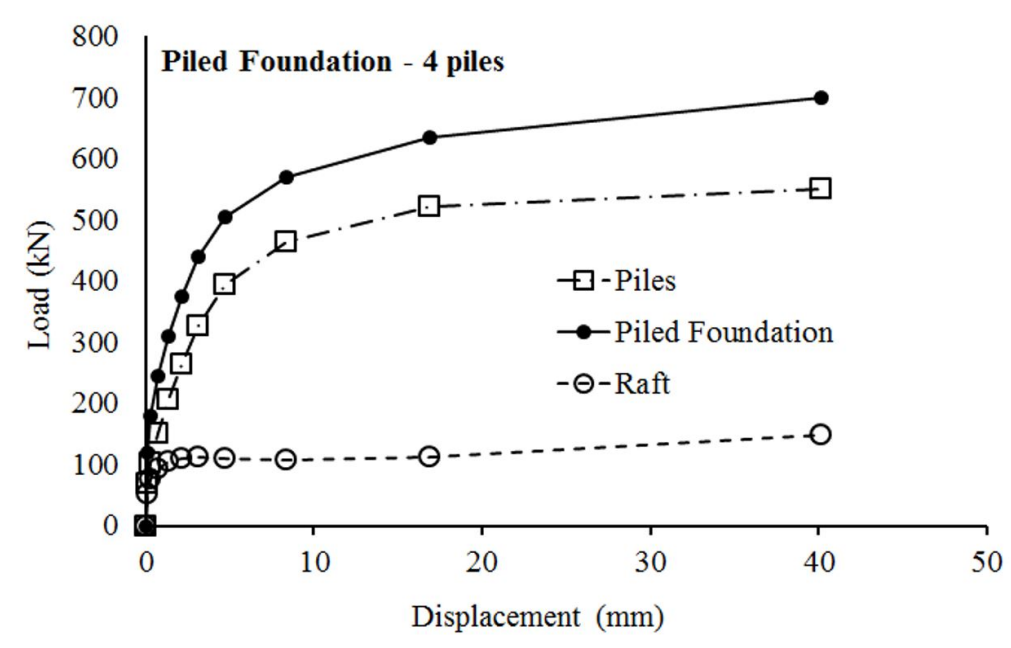

Figure 27: Load-displacement curve of piled foundation using four piles.

The interaction factor obtained for the piled foundations presents $\alpha_{\mathrm{rp}}$ values that are different from those observed by Clancy \& Randolph (1992), since the area and geometry of piled foundations used in this research are variable (Figure 28). The interaction between piles and the raft decreases as the number of piles increases, since the area of contact with the soil increases.

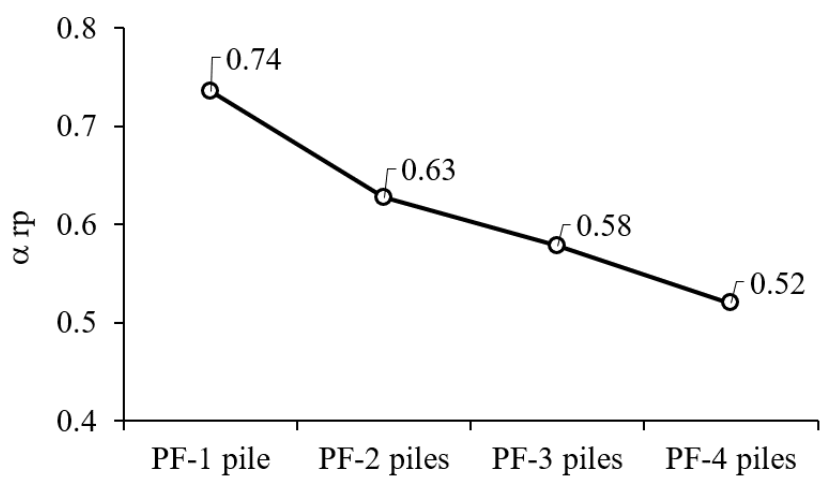

Figure 28: Interaction factor variation

The relative stiffness of deep foundation elements, obtained from the initial stretch of the load-displacement curve, increases as the number of piles increases, except for the piled foundation with three piles, which presents divergent and significantly lower results when compared to the other analyzed foundations (Table 9).

The plan area inertia of the raft tends to exert influence on the stiffness of the shallow foundation element and on the way, it distributes the loads for the pile group and for the soil. Despite this influence, the contribution from raft-soil contact was $14.4 \%, 27.5 \%, 22.4 \%$ and $21.3 \%$ for piled foundations with one, two, three and four piles, respectively (Figure 29). 


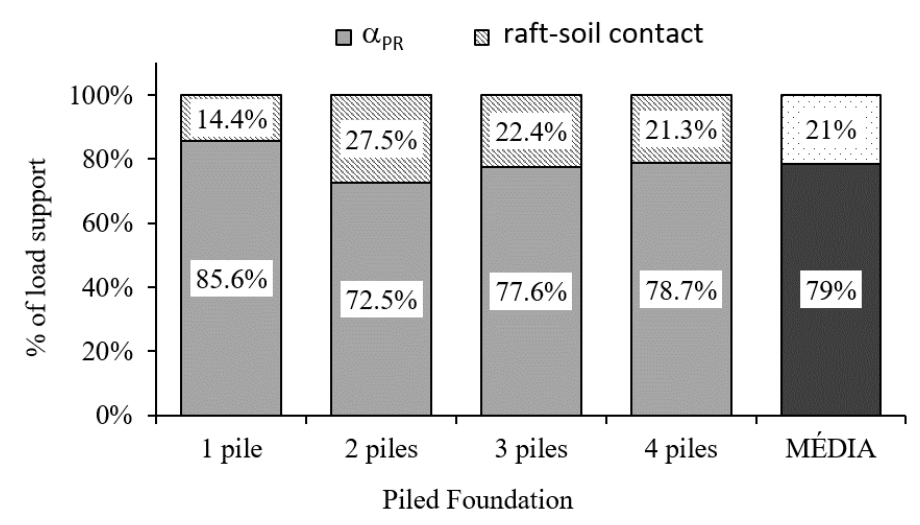

Figure 29: Contribution of piles group $\left(\alpha_{P R}\right)$ and raft-soil contact.

\section{CONCLUSIONS}

Considering the analyses and discussions of this study, the following conclusions can be presented:

- $\quad$ The piled raft foundation system, i.e., when the piled foundation considers strength from block-soil contact in its dimensioning, it presents superior load capacity to the conventional system using pile groups;

- Load capacity gains from soil contact depends on geomechanical characteristics of the soil where it is based, however, even for tropical Brazilian soil (porous clay) which possesses a high void index, its important contribution to load capacity can be verified;

- In blocks of a height capable of making them stiff or semi-stiff, block-soil contact enables the technical and economical optimization of geotechnical design, even for high loads, standardizing the structural load on top of the piles;

- $\quad$ For piled raft foundations composed of piles spaced with five times their nominal diameter, the contribution of contact was around $21 \%$, showing that even for porous soils, block-soil contact aids in improving load capacity;

- The loading capacity of piled rafts increased concomitantly with the increase in the ratio between the net area of soil-block contact and the total foundation plan area (Anet/Atotal). However, this cannot be established generally, since it also depends on the number of piles that compose the group and on the resistance characteristics of the soil mass;

- $\quad$ The instrumentation using digital strength gauges was important and appropriate to determine load values at the top and tip of piles during the realization of the static loading test, providing information about load transfer in deep areas;

The $\xi_{\mathrm{PR}}$ and $\mathrm{R}_{\mathrm{M}}$ indices of piled foundations with 3 and 4 piles showed similar results to those found by Conte et al. (2003) and Soares et al. (2015);

- $\quad \alpha_{U R}$ efficiency values obtained for the foundations analyzed in this research (2, 3 and 4 piles) displayed adequate accordance in comparison to those found by De Sanctis \& Mandolini (2006) and Soares et al. (2015);

- The interaction factor obtained for the piled foundations showed different arp values from those observed by Clancy and Randolph (1992). Such a difference can be attributed to the base geometry of the piled foundations used in this study, which were variable.

- The stiffness of the raft interacting with the terrain and piles is influenced by the format (geometry) of the plan block, impacting load absorption values through the contact block-soil and block-pile, and not only through the increase in the net area of contact and number of piles under the block.

\section{Acknowledgements}

The authors would like to thank Espaço da Escrita - Pró-Reitoria de Pesquisa - UNICAMP - for the language services provided and to Fundação de Amparo à Pesquisa do Estado de São Paulo (project n ${ }^{\circ} 11 / 17959-3$ ) 
Author's Contributions: Conceptualization, JR Garcia and PJR Albuquerque; Funding acquisition, PJR Albuquerque; Investigation, JR Garcia; Methodology, JR Garcia and PJR Albuquerque; Writing - original draft, JR Garcia and PJR Albuquerque; Writing - review \& editing, JR Garcia and PJR Albuquerque; Supervision, JR Garcia.

Editor: Marcílio Alves.

\section{References}

ABNT NBR 12.131. 2006. Estacas - Prova de carga estática - Método de ensaio

ABNT NBR 5738. 2015. Concreto - Procedimento para moldagem e cura de corpos de prova

ABNT NBR 5739. 2018. Concreto - Ensaio de compressão de corpos de prova cilíndricos.

Australian Standard. 2009. AS 2159 - Piling design and installation

British Standard. 2015. BS 8004 - Code of pratice for foundations

Chung. N.D, Kim, D, Jo, S. 2013. Settlement of piled rafts with different pile arrangement schemes via centrifuge tests. Journal of Geotechnical and Geoenvironmental Engineering; 139(10): 1690-8.

Clancy P. and Randolph M.F. (1992), Analysis and Design of Piled Raft Foundations, Research Report No. G1062, Department of Civil Engineering, The University of Western Australia.

Conte, G., Mandolini, A., and Randolph, M.F. 2003. Centrifuge modelling to investigate the performance of piled rafts. In BAP IV, International Geotechnical Seminar on Deep Foundations on Bored and Auger Piles. Vol.1. p. 359-366.

Décourt, L. 2008. Provas de carga em estacas podem dizer muito mais do que têm dito. In VI SEFE. Fundações profundas 1 . p. 221-245. São Paulo: ABMS.

De Sanctis, L., and Mandolini, A. 2006. Bearing Capacity of Piled Rafts on Soft Clay Soils. Journal of Geotechnical and Geoenvironmental Engineering, 132(December): 1600-1610. doi:10.1061/(ASCE)1090-0241(2006)132:12(1600).

De Sanctis, L., Mandolini, A. 2003. On the ultimate vertical load of piled rafts on the soft clay soils. In: Proceedings of 4th international geotechnical seminar on deep foundation on bored and auger piles. Ghent: Millpress. p. 379-86.

Eurocode 7. 1997. Geotechnical design - Part 1: Geotechnical design - Part 1: general rules.

Fleming, W.G.K., Weltman, A.J., Randolph, M.F., and Elson, W.K. 1992. Piling Engineering. In 2nd edition. Halsted Press. 390p.

Garcia, J.R. 2015. Análise experimental e numérica de radiers estaqueados executados em solo da região de Campinas/SP". Tese de Doutorado. Faculdade de Engenharia Civil, Arquitetura e Urbanismo, Universidade Estadual de Campinas. Campinas, Brazil.

Garcia, J.R., and Albuquerque, P.J.R. 2018. 3D Numerical Modeling applied to analysis of piled foundations. Revista chilena de ingeniería, 26(4).

Gon, F.S. 2011. Caracterização geotécnica através de ensaios de laboratório de um solo de diabásio da região de Campinas/SP. Dissertação de Mestrado. Faculdade de Engenharia Civil, Arquitetura e Urbanismo, Universidade Estadual de Campinas, Brazil.

Institute of Civil Engineers. 2012. Manual of geotechnical engineering: Volume II. 612p.

Janda, T., Cunha, R. P., Kuklik, P. E Anjos, G.M. 2009. Three-dimensional finite element analysis and back-analysis of CDA standard pile groups and piled rafts founded on tropical soil. Soil and Rocks, Vol. 32, n. 1, p. 3-18.

Leung, Y.F., Klar, A., Soga, K. 2010.Theoretical study on the pile length optimization of pile groups and piled rafts. Journal of Geotechnical and Geoenvironmental Engineering; 136(2): 319-30.

Makarchian, M., Poulos, H.G. 1994. Underpinning by piles: A numerical study. In: Proceedings of the 13th International Conference on Soil Mechanics and Foundation Engineering, Vol.4. New Delhi. p. 1467-70.

Mandolini, A. 2003. Design of piled raft foundations: practice and development. In BAP IV, International Geotechnical Seminar on Deep Foundations on Bored and Auger Piles. Vol.1. pp. 59-80. 
Mandolini, A., Di Laora, R., and Mascarucci, Y. 2013. Rational Design of Piled Raft. Procedia Engineering, 57(0): 45-52. Elsevier B.V.doi:10.1016/j.proeng.2013.04.008.

Novak, J.L., Reese, L.C., Wang, S.T. 2005. Analysis of pile-raft foundations with the 3D finite element method. In: Structures Congress 2005: Metropolis and Beyond. ASCE. https://doi.org/10.1061/40753(171)93.

Omeman, Z.M. 2012. Load sharing of piled-raft foundations in sand subjected to vertical loads. PhD Thesis. Montreal, Canada: Concordia University. 131p.

Poulos, H. G., Small, J. C., E Chow, H. 2011. Piled Raft Foundations for Tall Buildings. Geotechnical Engineering, 42(2), $78-84$.

Poulos, H.G. 2000. 16. Practical design procedures for piled raft foundations. In Design applications of raft foundations. Thomas Telford Publishing. pp. 425-467. doi:10.1680/daorf.27657.0016.

Poulos, H.G. 2001. Piled raft foundations: design and applications. Géotechnique, 51(2): 95-113. doi:10.1680/geot.2001.51.2.95.

Poulos, H.G., and Davis, E.H. 1980. Pile Foundation Analysis and Design. Rainbom-Bridge Book Co. Available from https://books.google.com.br/books?id=bqVIPgAACAAJ.

Randolph, M.F. 1994. Design Methods for pile groups and pile rafts. In XIII International Conference on Soil Mechanics and Foundation Engineering. ISSMGE, New Delhi. pp. 61-82.

Russo, G., Poulos, H. G., Small, J. C. 2013. Re-assessment of foundation settlements for the Burj Khalifa, Dubai. Acta Geotéchnica, v. 8, p. 3-15.

Sales, M.M. 2000. Behavior analysis of piled rafts. Civil and Environmental Engineering Department, University of Brasilia, DF, Brazil.

Soares, W.C., Coutinho, R.Q., and Cunha, R.P. da. 2015. Piled raft with hollow auger piles founded in a Brazilian granular deposit. Canadian Geotechnical Journal, 52(8): 1005-1022. doi:10.1139/cgj-2014-0087.

Teixeira, A.H., and Godoy, N.S. de. 2016. Análise, projeto e execução de fundações rasas. In Fundações: teoria e prática, 2nd edition. Edited by W. Hachich, F.F. Falconi, J.L. Saes, R.G.Q. Frota, C.S. Carvalho, and S. Niyama. Pini Ltda, São Paulo. p. 802.

Terzaghi, K., Peck, R.B., and Mesri, G. 1996. Soil Mechanics in Engineering Practice. In 3rd edition. John Wiley \& Sons, Inc., New York-Chichester-Brisbane-Toronto-Singapure. 565p.

Van Der Veen, C. 1953. International Conference on Soil Mechanics and Foundation Engineering. In III ICSMFE. p. 84-90. New Delhi.

Viggiani, C. Mandolini, A. Russo, G. 2012. Piles and Pile Foundations. Editora: Spon Press - New York - USA. 278p.

Zuquette, L.V. 1987. Análise crítica da cartografia geotécnica e proposta metodológica para condições brasileiras. Escola de Engenharia de São Carlos, Universidade de São Paulo, Brazil. 